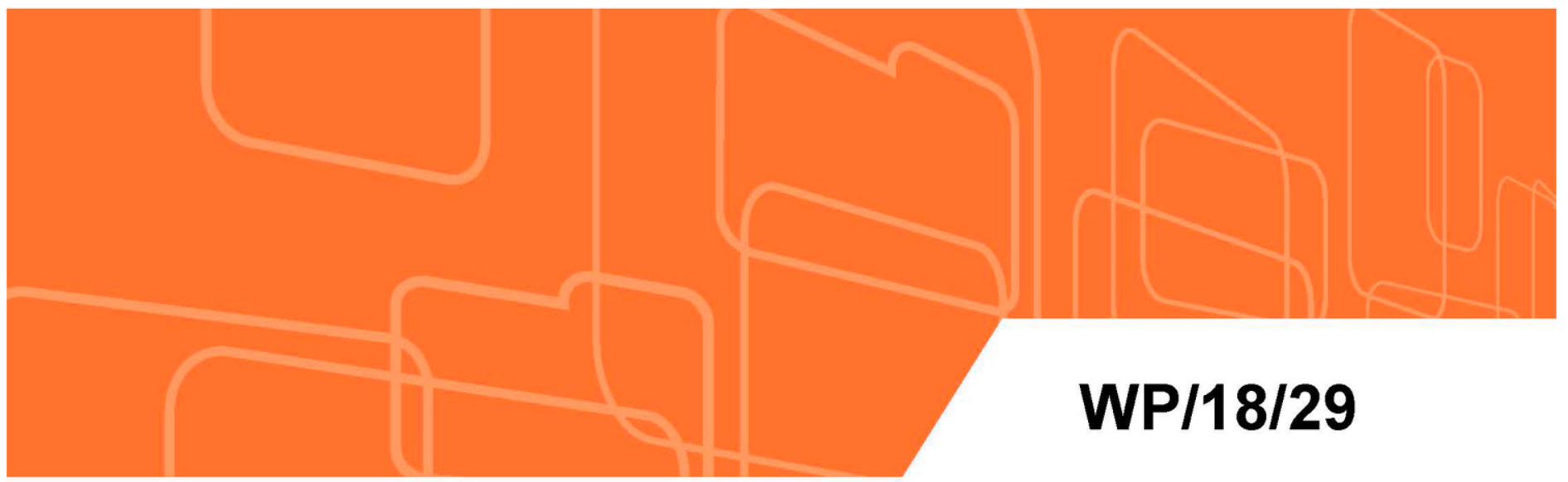

\title{
Portfolio Inflows Eclipsing Banking Inflows: Alternative Facts?
}

Eugenio Cerutti and Gee Hee Hong

IMF Working Papers describe research in progress by the author(s) and are published to elicit comments and to encourage debate. The views expressed in IMF Working Papers are those of the author(s) and do not necessarily represent the views of the IMF, its Executive Board, or IMF management.

I N T E R N A T I O N A L M O N E T A R Y F U N D 


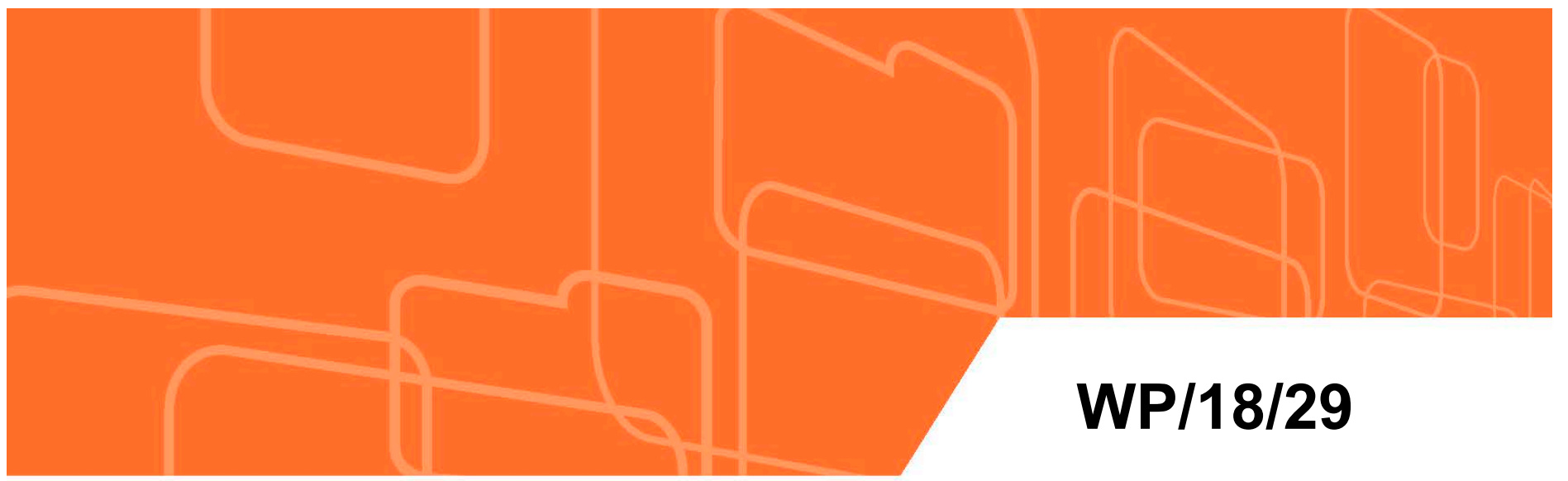

\section{IMF Working Paper}

\section{Portfolio Inflows Eclipsing Banking Inflows: Alternative Facts?}

Eugenio Cerutti and Gee Hee Hong

IMF Working Papers describe research in progress by the author(s) and are published to elicit comments and to encourage debate. The views expressed in IMF Working Papers are those of the author(s) and do not necessarily represent the views of the IMF, its Executive Board, or IMF management.
I $\mathbf{N}$
T E R
N A T | O N A L
M O N E T A R Y
$F \cup \mathbb{N}$ 


\title{
Portfolio Inflows Eclipsing Banking Inflows: Alternative Facts?
}

\author{
by Eugenio Cerutti and Gee Hee Hong ${ }^{1}$
}

February 2018

\begin{abstract}
Superficial examination of aggregate gross cross-border capital inflow data suggests that there was no substitution between portfolio inflows and bank loans in recent years. However, our novel analysis of disaggregate inflows (both by types of instrument and borrower) shows interesting heterogeneity. There has been substitution of bank loans for portfolio debt securities not only in the case of corporate and sovereign borrowers in advanced countries, but also sovereign borrowers in emerging countries. In the case of corporate borrowers in emerging markets, the relationship corresponds to complementarity across types of gross capital inflows, especially during periods of positive capital gross inflows after the global financial crisis. A large part of these patterns does not seem to be driven by a common phenomenon across countries associated with the global financial cycle, but rather by country-specific factors.
\end{abstract}

JEL Classification Numbers: F00, F2, F21, F3, F32, F41, F42

Keywords: capital flows, portfolio inflows, bank inflows, global financial cycle

Author's E-Mail Address: Ecerutti@imf.org, Ghong@imf.org

\footnotetext{
${ }^{1}$ Cerutti and Hong are both at the Research Department of the International Monetary Fund (IMF). We are grateful to Stijn Claessens, Giovanni Dell'Ariccia, Sebnem Kalemli-Ozcan, Sole Martinez-Peria, Maury Obstfeld, Rhiannon Sowerbutts, as well as seminar participants at IM-TCD-ND workshop on International Macroeconomics and Capital Flows (Dublin, Ireland) and an IMF seminar for useful comments, and to Haonan Zhou for extensive help with the data. Emails: ecerutti@imf.org; ghong@imf.org. The opinions expressed herein are solely the responsibility of the authors and should not be interpreted as reflecting those of the IMF, its Executive Board, or IMF management
} 


\section{INTRODUCTION}

The collapse in international capital inflows during the global financial crisis has proven to be very persistent. Capital inflows fell sharply during the crisis, and have only partially recovered in recent years to about one third of their pre-crisis (2003-07) global GDP average. This phenomenon and the heterogeneity behind the aggregate numbers are receiving increasing attention in the literature (e.g., Bluedorn et al 2013, Bussière et al 2016, and Advjiev et al 2017). ${ }^{2}$ Most of the decline in capital inflows has been experienced in Advanced Economies (AEs) rather than in Emerging Markets (EMs). And, in terms of the type of capital flows, most of the decline has taken place in portfolio inflows (equity and debt securities) and 'other investments' (which are often related to the lending of activity of international banks), while FDI inflows have proved to be more resilient (See Figure 1).

Despite such overall decrease in both portfolio inflows and 'other investments', their respective falls have not been similar, and there has been a substantial change in the composition of nonFDI related inflows. ${ }^{3}$ At the aggregate worldwide level, this is especially the case with portfolio inflows, which went from representing about half of total non-FDI inflows during the pre-crisis period (2003-07) to representing above 80 percent during 2008-16. Such increase in portfolio inflows was met by a decline of other components, particularly, the 'other investment' category whose share dropped to below 20 percent after the crisis. Furthermore, the breakdown by borrower sectors also displays a high degree of heterogeneity in the patterns of capital flows. While the share of non-FDI inflows to corporates slightly declined to below half during the crisis period (2008-12) and then jumped to about three quarters during the post crisis (201316), non-FDI gross inflows to banks represent about 15 percent during the post-crisis period (about half of their pre-crisis share). At the same time, the share to sovereign borrowers increased from negative inflows during the pre-crisis, to about half of inflows during the crisis, and 10 percent during the post crisis period. ${ }^{4}$

In this context, three questions arise to understand the nature of the increased share of portfolio flows in non-FDI capital inflows: Were any borrowers substituting international bank-related inflows with either portfolio debt or equity inflows during the period 2003-16? If so, are these relationships driven by negative or positive gross inflows? Was this a common phenomenon across countries and type of borrowers (banks, corporates, and sovereigns)?

\footnotetext{
${ }^{2}$ We follow the recent literature that focuses attention on non-resident capital inflows (usually denominated gross inflows) in our analysis. See next section for further description of the data, and Obstfeld (2012) for the importance of taking gross inflows into account in the analysis of capital inflows.

${ }^{3}$ FDI inflows have been historically more stable and less volatile than both portfolio and 'other investment' inflows (Bluedorn at al 2013; Hoggarth et al 2016; Eichengreen et al 2017), as well as less sensitive to changes in the global financial conditions (Cerutti et al 2015). Since a breakdown of FDI inflows by type of borrowers is not available, and since FDI flows seem to be driven by longer term considerations, the focus of the paper is on non-FDI inflows. See also Blanchard and Acalin (2016) and Lane and Milesi-Ferretti (2017) for some recent analysis of the drivers behind FDI flows.

${ }^{4}$ Negative gross inflows indicate that the flow has reversed, with non-residents liquidating their claims.
} 
Figure 1. Global Evolution of Capital Inflows by Instrument Type

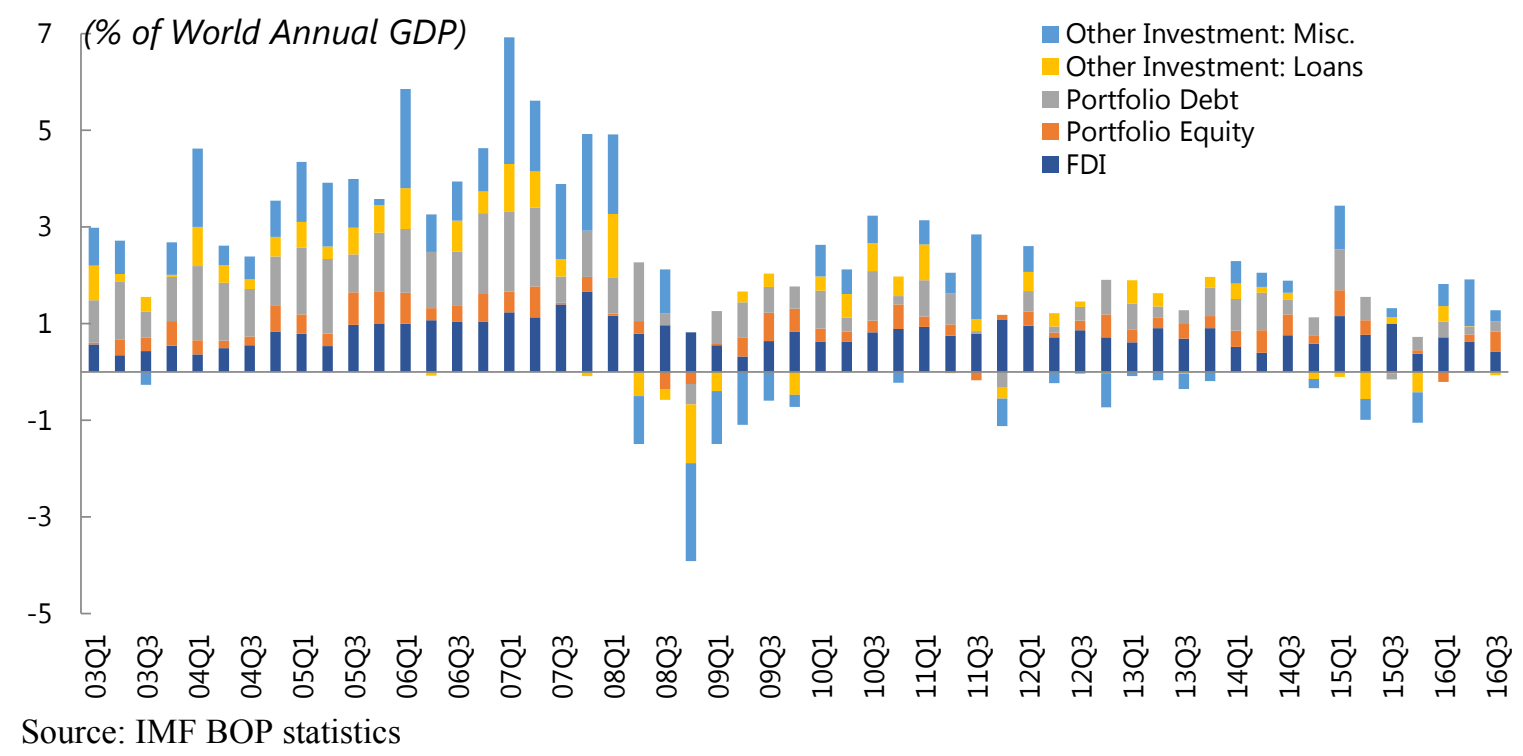

Two recent studies highlight the importance of using disaggregate gross capital inflows data and show that the analysis of aggregate inflows is not necessarily indicative of the underlying relationships of disaggregate capital flows. Galstyan et al (2016), using IMF Coordinated Portfolio Investment Survey (CPIS) data, examine separately portfolio debt and equity, distinguishing by the sectoral identity of the holder of the security, and find that a full understanding of cross-border portfolio positions requires granular-level analysis. More related to our study, Advjiev et al (2017), using mostly Balance of Payments (BOP) data, analyze the borrower type decomposition of the evolution of two type of instruments: portfolio inflows and other investment inflows. They analyze 85 countries ( 25 advanced, 34 emerging, and 26 developing economies) during 1996-2014, and highlight that empirical regularities that characterize aggregate inflows do not hold for all borrowing sectors, either with respect to their evolution or their sensitivity to proxies to the global financial cycle, such as VIX variables.

In this context, our paper adds value on two aspects. First, we continue the direction of Advjiev et al (2017) and break down gross capital inflows further by type of instruments, distinguishing between debt securities and equity in the case of portfolio inflows, as well as loans (made by international banks) and the remainder (mostly in the form of currency and deposits, trade credit and advances, and other accounts receivable/payable, etc.; which we label other investment miscellaneous) in the case of 'other investments'. Such expanded breakdown is captured in the red squares of Figure 2. Furthermore, for each of these categories, we identify how much of the flows by each instrument was allocated to borrowers' corporate, bank, and sovereign sectors. As a result, we compile a novel dataset with those wider instrument breakdowns by each of the 3 types of borrowers for 43 countries (21 AEs and $22 \mathrm{EMs}$ ). We are the first, to our knowledge, to take advantage of these detailed BOP data breakdown. ${ }^{5}$

\footnotetext{
${ }^{5}$ As detailed in the next section, we mostly use BOP data based on the newer BPM6 classification, but in a few cases, we were able to complete some parts of the dataset using BOP old series based on BPM5, which are
} 
Our additional breakdowns by type of instrument offer merits in the following sense. By distinguishing portfolio debt and equity, our work makes a closer connection to the finance theory of capital structure. There are clear differences between borrowing through portfolio debt and equity as shown in the rich literature on optimal capital structures, where companies trade off benefits (e.g. tax benefits) and costs (e.g., financial distress costs; agency costs) of debt financing (see Modigliani and Miller, 1963; Jensen and Meckling, 1976, Tirole, 2006). Similarly, separating loans from other investment clarifies the object of interest. Loans in the BOP data usually represent the largest sub-category of the general 'other investment' category and they are directly linked by definition to international banks' activity. As stated in the BOP data compilation methodology, "loans" correspond to cross-border loans from deposit-taking institutions to non-affiliates. The evolution of other investment miscellaneous is much more volatile and international banks are not necessarily the non-resident lenders behind these inflows.

Figure 2. Breakdown of Non-resident Inflows by Type of Flows

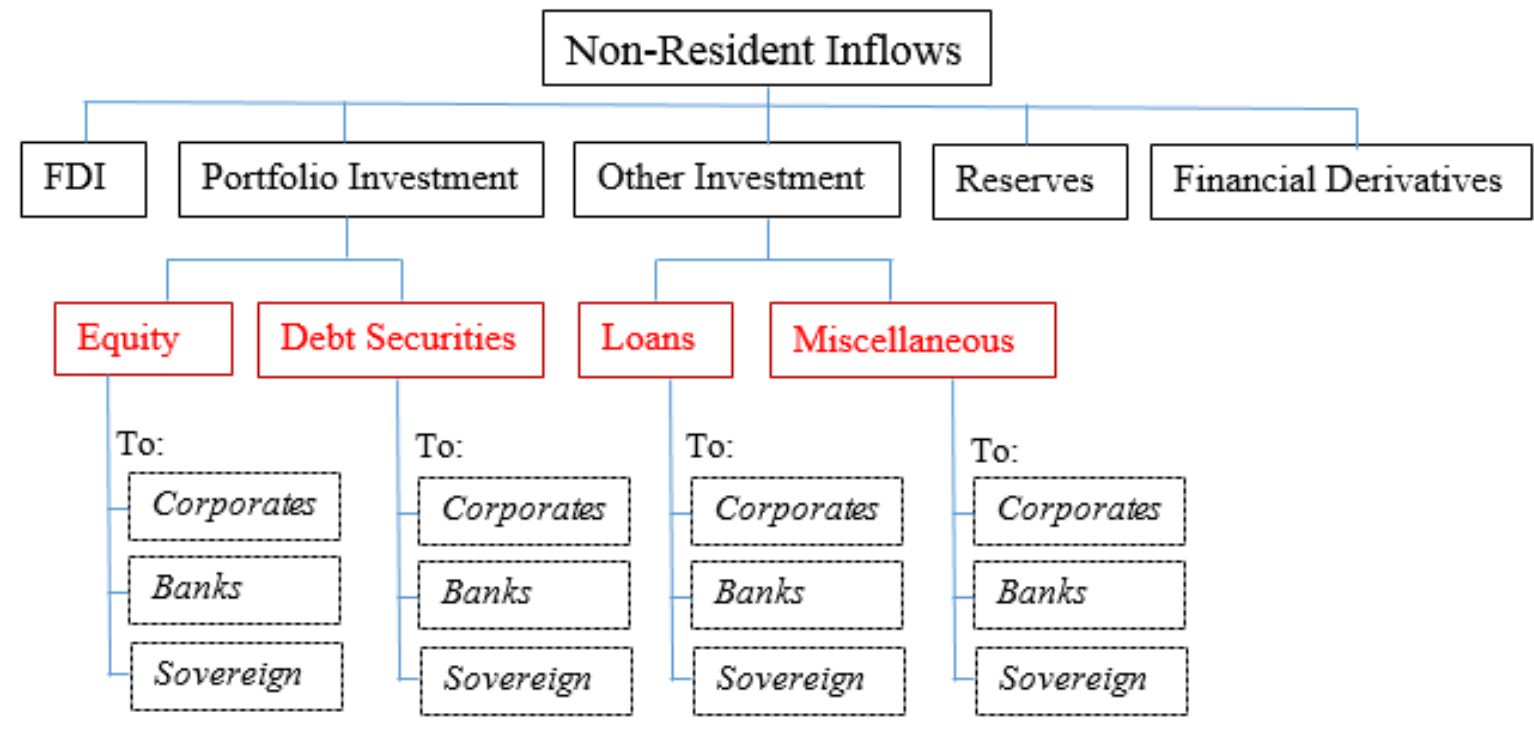

Notes: This breakdown follows the Balance of Payment Manual 6. The types of capital inflows analyzed in this paper correspond to the breakdown of Portfolio Investment and Other Investment into Equity, Debt Securities, Loans, and Miscellaneous (red squares in the figure). Miscellaneous includes the subcategories: currency and deposits, trade credit and advances, other account receivable/payable, non-life insurance technical reserves, life insurance and annuities entitlements, pension entitlements, provisions for calls under standardized guarantees, and SDR allocations.

internally available in IMF archives. Unlike Advjiev et al (2017), we do not need to combine BOP data with other non-BOP sources to compile our dataset, even though this constrains us to a shorter time span 2003Q12016Q2 (instead of their 1996Q1-2014Q4) and to focus our attention on only AEs and EMs. For our paper's objectives, it is better to focus on getting the additional available BOP breakdowns rather than less details that would permit a longer and wider country coverage. 
Second, and more importantly, we focus on the patterns between the type of flows in order to highlight any complementarity and substitution patterns across the three types of borrowers (banks, corporates, and sovereigns), while also considering the global financial cycle. We label as 'substitution' cases where two types of capital inflows are moving in opposite directions within a given quarter (e.g. an increase in portfolio debt inflows happens together with a decline in other investment loans), and as 'complementary' when two types of inflows are moving in same direction within a given quarter. ${ }^{6}$ Although our results should be interpreted with caution, given the difficulties of effectively controlling for demand and supply factors, the sign of the correlations are informative with regard to the relative evolution among the different types of capital inflows. For example, a complementarity relationship might reflect that borrowers are able to borrow more across different type of inflows because non-residents increase their supply of funds due to changes in the global financial cycle. We capture the potential supply influence of the global financial cycle using common factors that allow us to tease out in an innovative way, whether or not substitution or complementary patterns are associated with global co-movements or more idiosyncratic factors. More specifically, using the dynamic common factor technique introduced by Kose et al (2003), we compute the comovement across countries for each type of instrument (portfolio debt, portfolio equity, other investment loans, and other investment miscellaneous) as well as sub-factors for each of the borrower types. We then decompose each capital inflow series into two components: (i) predicted values driven by the global factor and borrower-type sub-factors, and (ii) a residual component reflecting country-specific factors. ${ }^{7}$

Our key findings can be summarized in three main points: First, while some document that at the aggregate level, there was no substitution between types of gross capital flows (e.g., as explicitly highlighted in Bussière et al. 2016), we find evidence of some degree of substitution in the case of AE corporates during 2008-16; as well as in the case of both AE and EM sovereign throughout the sample period when performing a more detailed analysis. These substitution relationships were especially strong and significant between the two larger instruments, portfolio debt and loans. The opposite seems to be true in the case of EMs' corporates, which show a complementary relationship between portfolio debt inflows and international bank loans. Second, in most cases, statistically significant complementarity or substitution relationships were present when there was an increase in non-residents' debt

\footnotetext{
${ }^{6}$ This is a looser terminology than what is used in microeconomics where prices are considered, but estimating demand functions with aggregate data is far from possible.

${ }^{7}$ Instead of proxying the global financial crisis through some push variables (e.g. US VIX as in Forbes and Warnok 2012, Rey 2013, Advjiev et al. 2017; US global bank leverage as in Bruno and Shin 2015a, and even a set of monetary and banking variables from both US and Europe as in Cerutti, Claessens, and Ratnovski 2017 and Cerutti and Osorio-Buitron 2017), using a latent factor approach provides a very general way to identify commonality in flows and avoids having to determine which specific factors may drive the commonality. This is not a minor advantage given that common variables such as the VIX has started to be questioned in recent years as good proxies of the global financial cycle (see Shin 2016 and Cerutti Claessens, and Ratnovski 2017).
} 
securities inflows. The complementary relationships experienced by EM corporates since the crisis, and AE corporates before the crisis were driven by an increase in their borrowing through both debt securities and loans. The substitution relationship in the case of AE and EM sovereigns as well as AE corporates (since the crisis) reflects an increase in borrowing through debt securities, which replaced international bank loans. Only in the case of EM banks did a complementarity relationship during the peak of the crisis seem to have been driven by an outflow of both debt securities and loans. Third, the substitution/complementarity relationships seem to be explained more by idiosyncratic-country factors than a general factor common across countries. However, this also depends on the type of borrower sector and instrument type. While idiosyncratic components seem to play a larger role in explaining the substitution between loans and debt inflows to AE and EM sovereigns, both common and idiosyncratic factors drive the substitution (complementarity) between loans and debt inflows to AE corporates (EM corporates) since the crisis.

In this context, our results complement and shed light onto two areas of the policy debate on capital flows. First, the different type of relationship between debt security and loans for EM and AE corporate borrowers during the post-crisis period signal different realities. Our results for EMs put the literature on the new wave of debt financing (Shin, 2013, Lo Duca et al 2014, Avdjiev et al., 2016) in a broader context, highlighting that the documented large increase in bond borrowing (domestically or from abroad) from non-residents did not seem to trigger a general substitution in EM's private sectors. At the same time, our results for AEs are consistent with the strong evidence of domestic substitution between bank loans and bond financing highlighted by Becker and Ivashina (2014) using US firm level data during periods of tight lending standards, depressed aggregate lending, and poor bank performance. We find that this US behavior was also present in other AEs, where corporates substituted cross-border loans for debt-securities since the crisis. This pattern was not present before the crisis. AEs' corporates increased both their loans and debt-security borrowing during the pre-crisis period when non-residents largely increased their exposure to AEs, funding a large increase in external private sector debt which was one of the main causes of the crisis (see Reinhart and Rogoff, 2009).

Finally, our finding that the global financial cycle does not alone explain the complementarity/substitution relationships also contributes to the debate on the importance of the global financial cycle on capital flows. Our findings coincide with Advjiev et al. (2017)'s take away that empirical regularities that characterize aggregate inflows do not hold for all borrowing sectors, either with respect to their evolution or their sensitivity to the global financial cycle. We confirm the need to distinguish as much as possible between sovereign and non-sovereign capital inflows when analyzing their patterns and drivers. Furthermore, our results do not favor a view where gross cross-border flows are clearly moving in tandem across countries regardless of borrower characteristics (e.g., exchange rate regimes as in Passari and Rey 2015). Our results are more in line with Cerutti, Claessens, and Rose (2017), which finds little systematic evidence that the global financial cycle explains as much of the variation in 
capital flows. In addition, our findings that part of the substitution between loans and debt inflows into AE corporates was driven by common factors could help in explaining Barrot and Serven (2017) finding of larger synchronization in aggregate gross capital inflows to AEs than in those to EMs. Their aggregation across types of capital flows (and borrowers) could increase the cross-country synchronicity in case of substitution relationships between type of capital flows, especially if those are driven by a common factor.

The rest of the paper is structured as follows. Section II describes the data set used and presents stylized facts about some key patterns of international capital flows dynamics using the new data set. Section III presents empirical results in cross-country panel framework to assess the relationship between different types of capital flows. Section IV analyzes which direction of the non-resident flows (inflows or outflows) play a larger role. Section V studies the significance of common dynamics across countries as a determinant of capital flows patterns. Finally, in Section VI, we summarize and conclude.

\section{Data And Evolution of CAPital Inflows}

Our main dataset is the BOP data from the IMF, one of the most widely used data sets to study international capital flows. Our paper distinguishes itself from the existing work in the sense that we are the first, to our knowledge, to take advantage of the BOP data with detailed information available on borrower types for four different types of instruments of capital flows. As mentioned previously, the use of disaggregate capital flows data is similar in spirit to Advjiev et al. (2017), while we further expand the coverage to include different types of portfolio inflows (separately for debt securities and equity) as well as a breakdown of 'other investment' into loans and miscellaneous (which includes currency and deposits, trade credit and advances, and other accounts receivable/payable). In addition, we also further break down by three types of borrowers (banks, sovereigns, and corporates). ${ }^{8}$ The coverage of countries is large with 43 countries, and balanced across regions, with 21 AEs and 22 EMs (See Table 1).

\footnotetext{
${ }^{8}$ Our 'corporates' category covers the non-deposit taking institutions (banks) and the non-public sector, where the public sector is the result of adding central bank and other government. Avoiding the breakdown between central bank and general government simplifies the correspondence between BPM6 and BPM5 data. For example, BPM5 had a category "monetary authorities" instead of "central bank". Monetary authorities encompass the central bank (which subsumes other institutional units included in the central bank subsector, such as the currency board) and certain operations usually attributed to the central bank but sometimes carried out by other government institutions or commercial banks, such as government-owned commercial banks. In BPM6, the functional category of monetary authorities is supplementary, except for reserves assets. Where "monetary authorities" are supplementary, their transactions and positions need to be recorded as standard components under either central bank or general government, depending on the entity that holds the instrument on its books. Similarly, we do not use BPM6 further data breakdown of "other sectors" into "other financial corporations"; and "nonfinancial corporations, households and NPISHs". This additional breakdown is not available for all countries and it was not present in BPM5.
} 
We started the construction of the dataset by downloading all the available breakdowns using BPM6 classifications as well as aggregate categories. ${ }^{9}$ Using the aggregate categories and available breakdowns, we proceeded to fill in our target breakdowns. If BPM6 breakdowns were not enough, we checked if that information was there when BPM5 data was being reported, using the IMF internal IMF EDSS platform. We were able to complement the BPM6based dataset using the information available from the BPM5 dataset for the following cases: portfolio debt (US for period 2003-11, Spain 2003-07, Slovenia 2003-05, and Slovakia 200407); portfolio equity (US for period 2003-11, Iceland 2003-2016, Spain 2003-07, Czech R. 2003-05, and Slovakia 2004-07); and loans (Italy for period 2008-14, Netherlands 2004-14, Finland 2008-14, Hong Kong SAR 2003-12, Czech R. 2008-12, Slovakia 2004-14, Estonia 2009-14, Latvia 2003-10, Lithuania 2004-13, and Slovenia 2008-13).

The resulting data used for calculating the breakdown of the corporate borrowing into the four type of instruments seems very reliable for a large majority of countries/series in the sample, without missing or zero (or very small) values. The exceptions are many observations with equity inflows to the government sector equal to zero for several countries, but this seems appropriate. Other exceptions are some series with respect to banks or sovereign borrower sectors. In order to keep the highest data standards, mostly due to lack of reliable breakdowns when decomposing 'other investment' into loans and miscellaneous items (e.g., all the total for 'other investment" is only allocated under 'loans', leaving all the remaining categories with values of zeros which seems not reliable), we exclude in the regressions the observations of inflows by banks for the following five AE and two EM countries: Canada, Germany, Israel, Spain, UK, US, Colombia, and India. For a similar reason, we exclude observations of inflows by sovereign for the following four countries: Hong Kong SAR, Australia, India, and the US. ${ }^{10}$ The time coverage of our novel dataset is from 2003Q1 to 2016Q1, covering well the periods before, during, and after the global financial crisis and European crisis.

At the aggregate level, as reflected in Figures 3 and 4, there is a substantial variation in our sample in the movements of capital inflows across different borrower types and instrument types, which already indicates the potential misrepresentation of capital inflow movements by looking at aggregate dynamics only. These figures show the composition of capital inflows in

\footnotetext{
${ }^{9}$ With the September 2015 edition of the IMF International Financial Statistics, the IMF started redisseminating an economy's own official BPM6-basis estimates for all years for which the economy developed such estimates, and converted BPM5-basis estimates for years where there are no official BPM6-basis estimates. Hence, for some countries, not all breakdowns are publicly disseminated if country official BPM6basis estimates do not cover them retrospectively. We will rely on BP5 figures for completing many series. All large economies with the exception of China are in our 43-country sample. China's BOP data does not have the breakdown by borrowers at our level of type of instrument breakdown. Nevertheless, missing only one large country does not necessarily impact our core results, which exploit between country heterogeneity, and provide EM aggregates in the rest of the paper that are not merely driven by China.

${ }^{10}$ The results are robust to including those countries in the regressions analyzing the evolution of bank and sovereign loans.
} 
three different time periods of our sample: pre-crisis (2003Q1-2007Q4), crisis period (2008Q12012Q4) and post-crisis period (2013Q1-2016Q1).

Table 1. Sample of countries

\begin{tabular}{|l|l|l|}
\hline & $\begin{array}{l}\text { Advanced Economies } \\
\text { (21 countries) }\end{array}$ & $\begin{array}{l}\text { Emerging Economies } \\
\text { (22 countries) }\end{array}$ \\
\hline Country & Australia & Argentina \\
& Austria & Brazil \\
& Belgium & Chile \\
Canada & Colombia \\
& Hong Kong, Province of China & Croatia \\
& Denmark & Czech Republic \\
& Finland & Estonia \\
France & Hungary \\
& Germany & India \\
& Greece & Latvia \\
& Iceland & Lithuania \\
& Israel & Mexico \\
& Italy & Philippines \\
& Japan & Poland \\
& South Korea & Russian Federation \\
& The Netherlands & Slovak Republic \\
& New Zealand & Slovenia \\
& Spain & South Africa \\
& Sweden & Thailand \\
& United Kingdom & Turkey \\
& United States & Ukraine \\
& & Uruguay \\
\hline
\end{tabular}

The breakdown of capital inflows by type of instruments is presented in Figure 3 separately for AEs and EMs. In our sample of 43 countries, these charts confirm again the importance of distinguishing among instruments, since the patterns of each inflow during the crisis differs greatly. The collapse in other investment miscellaneous during the crisis is clear in both $\mathrm{AE}$ and EMs, turning even into negative inflows in the case of AEs. An increase in the share of portfolio debt inflows is also reflected for both AEs and EMs over time. This is also the case of portfolio equity inflows to AEs but not to EMs, where it declines over time. The evolution of other investment loan is more heterogeneous across country groupings and periods, but in general reflect a decline in share during the post-crisis period relative to the pre-crisis period. From the borrower perspective, Figure 4 shows that non-FDI capital inflows to sovereign increased since the crisis, while banks' shares declined, especially in AEs. Corporates increased their shares in AEs during the post-crisis period and remained relatively stable during the crisis period. 
Figure 3. Decomposition of Capital Inflows by Instruments
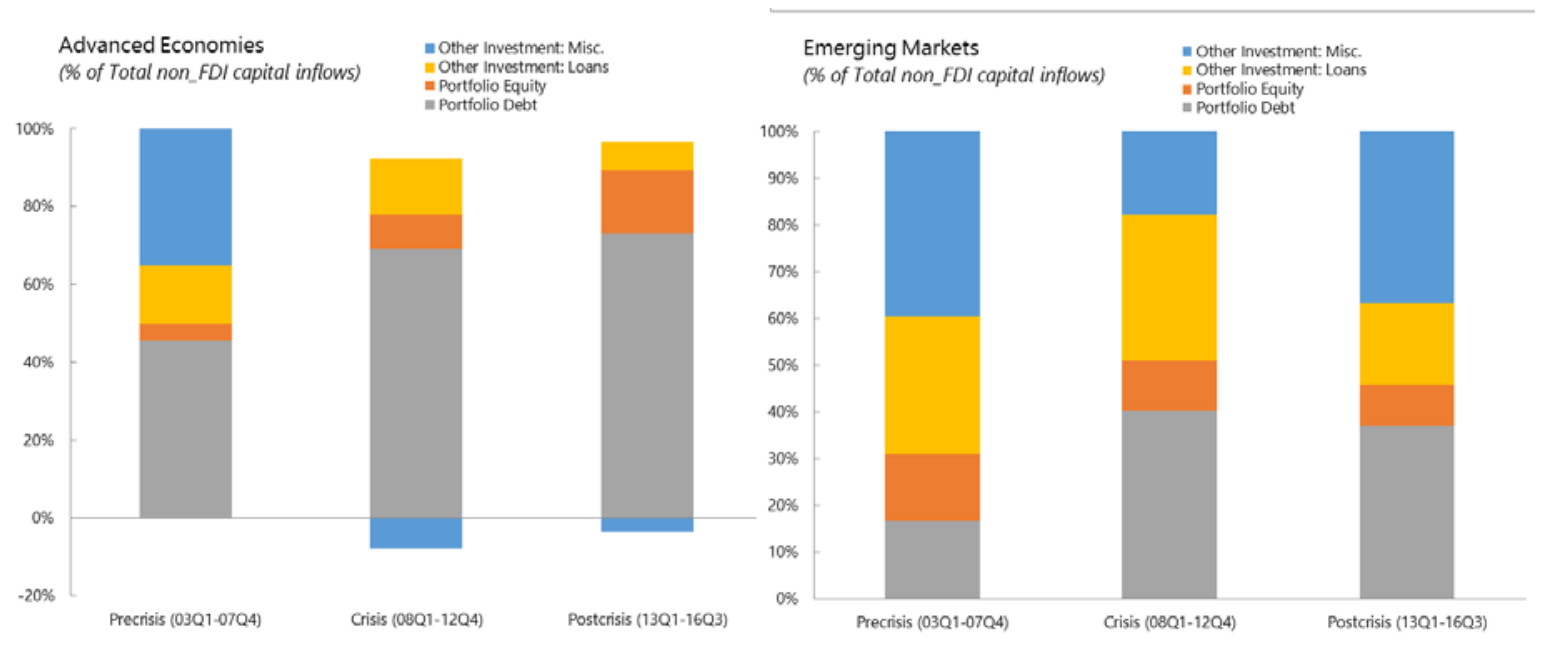

Source: IMF BOP statistics and authors' calculations

Figure 4. Decomposition of Capital Inflows by Borrower Type
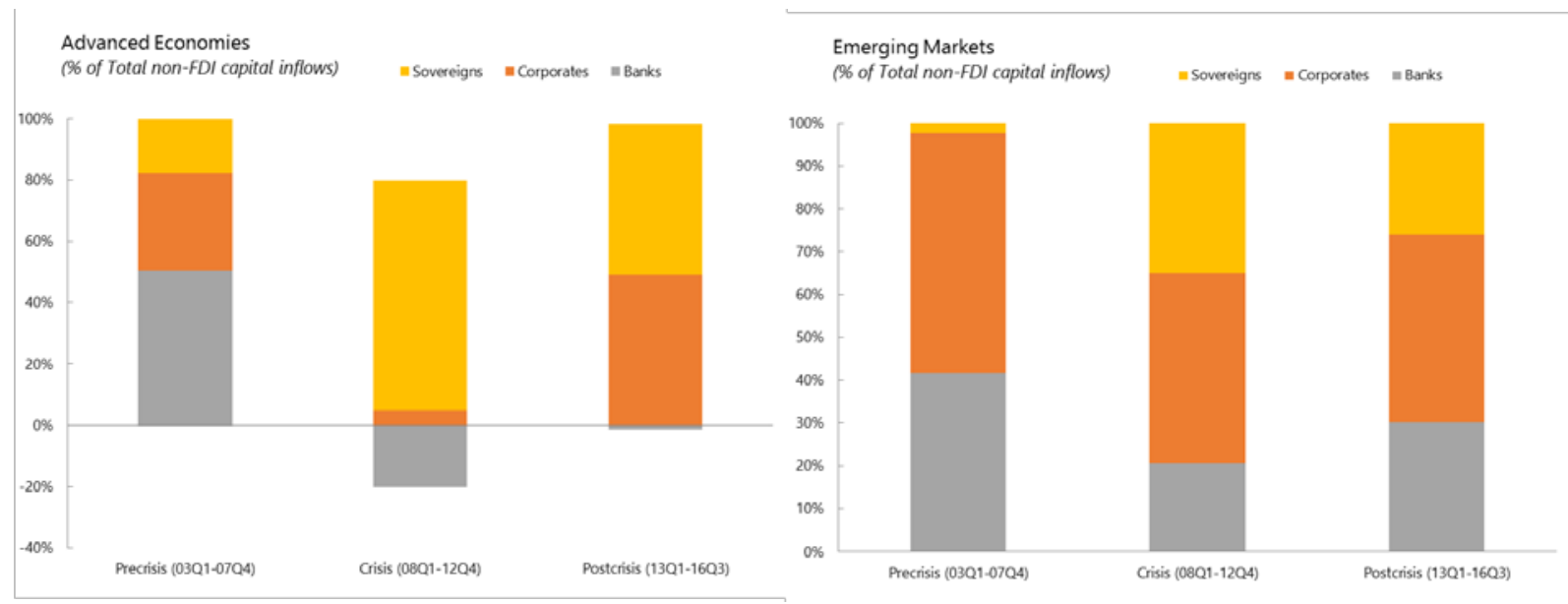

Source: IMF BOP statistics and authors' calculations

A more interesting breakdown, given our objectives in this paper, is to plot the quarterly evolution of capital inflows as a share of GDP to each borrowing sector, while also breaking them down by type of instruments. A set of very interesting patterns already emerges from this simple exercise, suggesting evidence of substitution - a rise in one type of inflow is accompanied by a decline in another-and/or complementary relationships between some type of instruments and periods. For example, the evolution of capital inflows to AE corporates (see Figure 5) shows that portfolio debt (grey bars) and other investment loans (yellow bars) were positively correlated during the pre-crisis period, which changed after the crisis, reflecting an apparent substitution pattern. The complementary is present during the entire period in the case of EM corporates (See Figure 6). Instead, it is clear that there has been substitution between portfolio debt and other investment loans for EM sovereigns, especially during the pre-crisis period (See Figure 7). 
Figure 5. Evolution of Gross Capital Inflows to Corporates, Advanced Economies (Corporates; percent of of AEs' GDP)

- Other Investment: Misc.

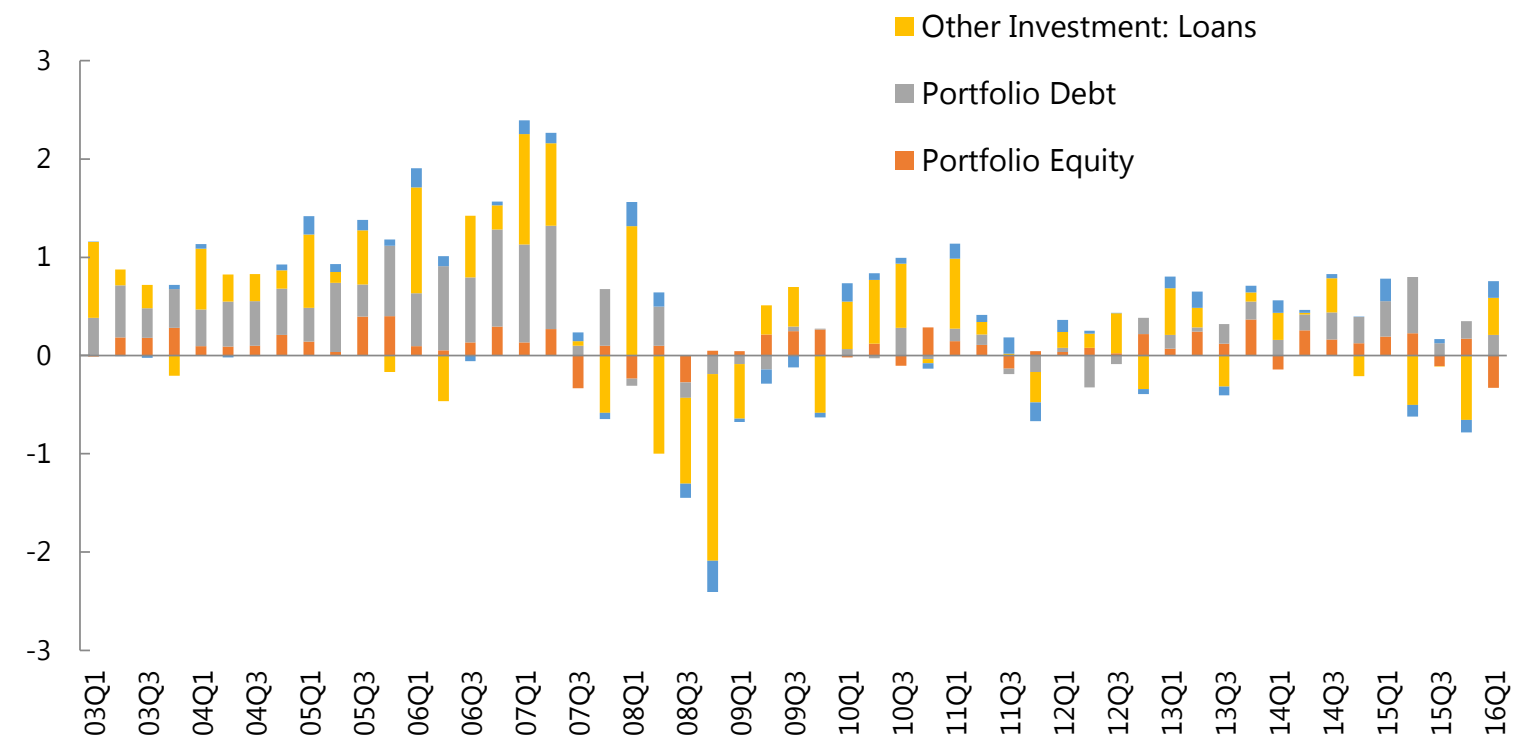

Source: IMF BOP statistics and authors' calculations

Figure 6. Evolution of Gross Capital Inflows to Corporates, Emerging Economies

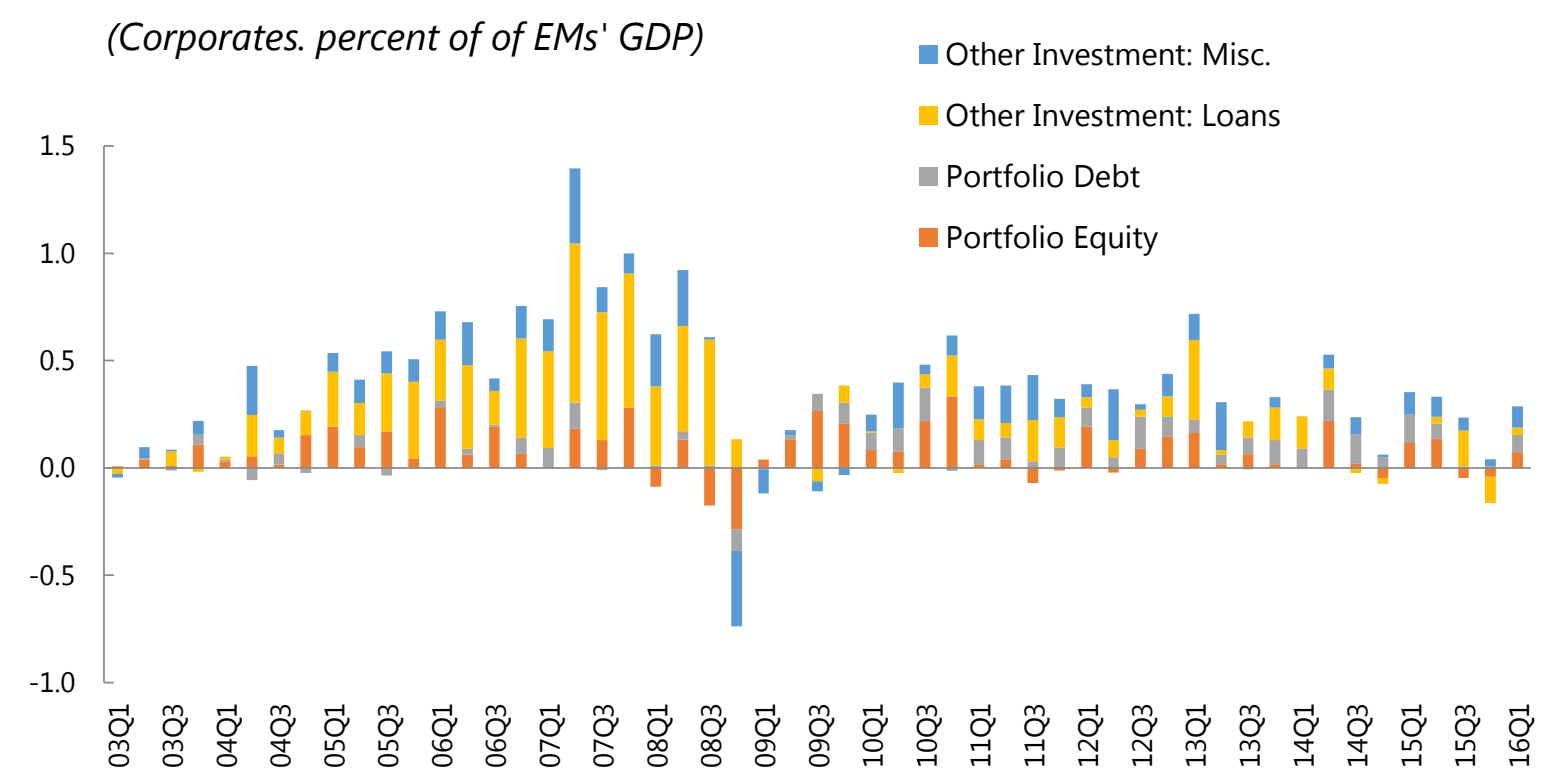

Source: IMF BOP statistics and authors' calculations 
Figure 7. Evolution of Gross Capital Inflows to Sovereigns, Emerging Economies

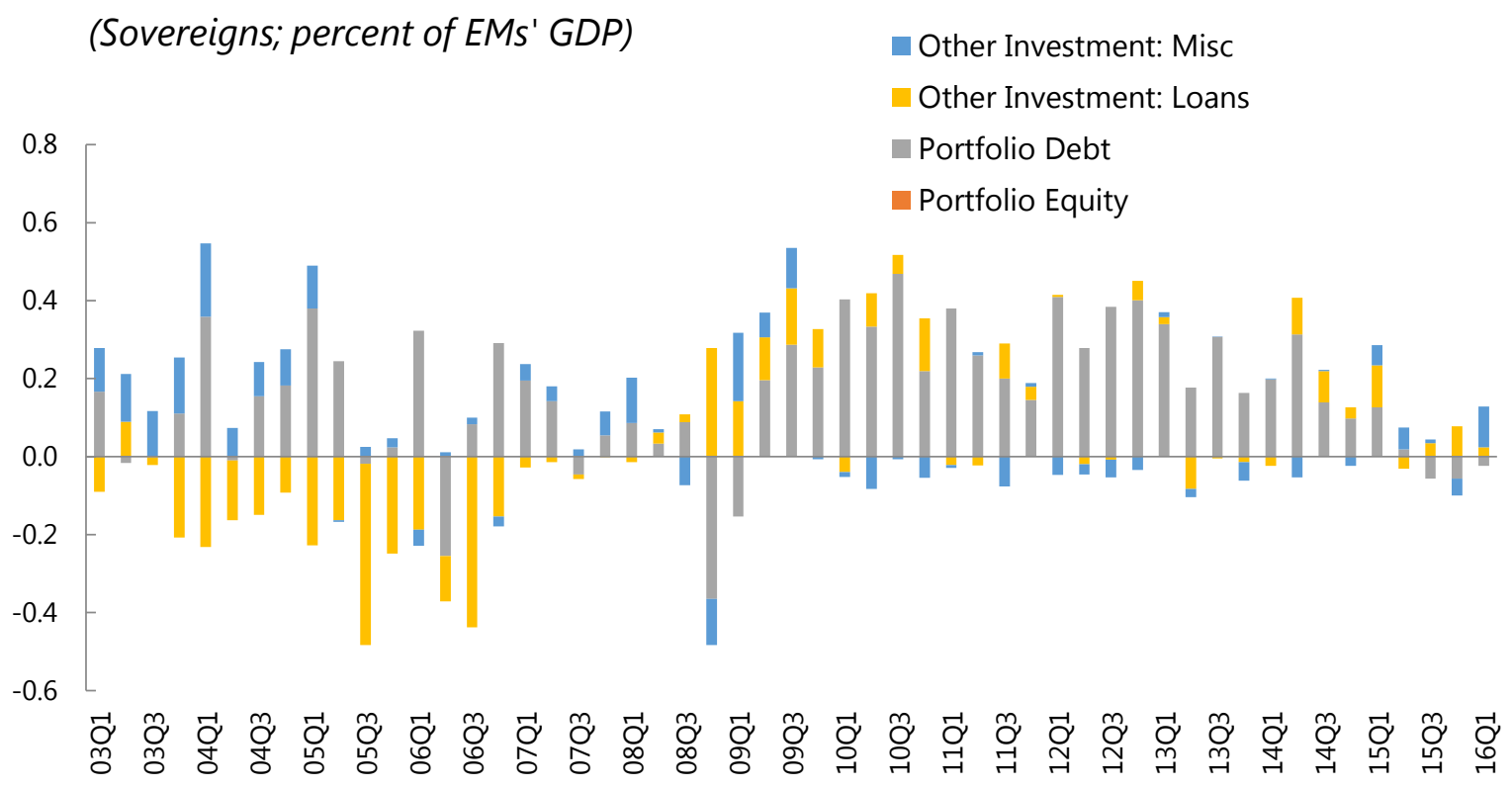

Source: IMF BOP statistics and authors' calculations

\section{Complements OR SubStitutes AT The Country LeVEl?}

Is the evidence of complementary and substitution patterns, as is shown when decomposing capital inflows by borrower type, also present across countries? Or is it merely the result of the aggregation of the countries' capital inflows, only observable at an aggregated level? In this section, we address this question by studying the relationship between different types of capital flows at the country-level. We run cross-country panel regressions separately for advanced economies and emerging economies. Our main dependent variable is the loans inflows of each country by each borrower type, s. Specifically, our cross-country panel specification is as follows:

$$
\begin{gathered}
\text { Inflow }_{i, t}^{\text {Loans }, s}=\alpha_{i}+\alpha_{t}+\beta_{1} \text { Inflow }_{i, t}^{\text {debt }, s}+\beta_{2} \text { Inflow }_{i, t}^{\text {equity }, s}+\beta_{3} \text { Inflow }_{i t}^{\text {miscellaneous }, s}+ \\
\text { GDP_growth }_{i, t-1}+u_{i, t}^{k s}
\end{gathered}
$$

where $\alpha_{i}$ is a country fixed-effect, $\alpha_{t}$ is a time fixed-effect, Inflow $w_{i, t}^{k s}$ is an inflow of country i of instrument $k$ (portfolio debt, portfolio equity and miscellaneous) and borrower type $s$, and lag GDP growth in country i. Note that each inflow variable is normalized by the country's GDP. Country and time fixed-effects are included to control for idiosyncratic borrower country factors and global time events that could affect the relative evolution of capital inflows. A positive coefficient would imply a complementary relationship with loans inflows; for instance, a rise in debt borrowing by corporates coinciding also with a rise in borrowing in terms of 
loans. Instead, a negative coefficient would indicate the presence of some substitution between loan inflows and the respective other type of capital inflow. ${ }^{11}$

Results are presented in columns (1), (3) and (5) of Table 2 for AEs, and the same columns of Table 3 for EMs. When constraining the coefficients for the entire 2003-16 sample period, the most statistically significant coefficients correspond to case of sovereigns in column (5). There, we find evidence that portfolio debt and loan inflows have negative correlations, suggestive of a persistent substitution between the two types throughout the sample period. This also seems to be the case between loan and miscellaneous inflows. ${ }^{12}$ Similar substitution trends are present in the case of $\mathrm{AE}$ corporates between loans and equity as well as $\mathrm{AE}$ banks between debt and loan inflows. We do not find statistically significant relationships between changes in countrylevel loans and the evolution of country-level capital inflows of other instruments in the case of EM corporates and banks.

As several recent studies have documented, the global financial crisis has had an important and persistent effect on the global capital inflows at the aggregate level, with the post-crisis level of capital inflows still below its pre-crisis average. In this context, there could clearly be material differences in the evolution of the types of inflows during the crisis. How about after the crisis? To address these questions, we further augment equation (1) by including crisis dummies and post-crisis dummies to see if there is a change in the relationship between capital inflows during the period under analysis. Specifically,

$$
\begin{aligned}
& \text { Inflow }_{i, t}^{\text {Loans }, s}=\alpha_{i}+\alpha_{t}+\beta_{1} \text { Inflow }_{i, t}^{\text {debt }, s}+\beta_{2} \text { Inflow }_{i, t}^{\text {equity }, s}+\beta_{3} \text { Inflow }_{i t}^{\text {miscellaneous }, s} \\
& +\gamma_{1} \text { Inflow }_{i, t}^{\text {debt }, s} * \text { crisis }+\gamma_{2} \text { Inflow }_{i, t}^{\text {equity }, s} * \text { crisis }+\gamma_{3} \text { Inflow }_{i, t}^{\text {miscellaneous }, s} * \text { crisis } \\
& +\theta_{1} \text { Inflow }_{i, t}^{\text {debt }, s} * \text { post }+\theta_{2} \text { Inflow }_{i, t}^{\text {equity }, s} * \text { post }+\theta_{3} \text { Inflow }_{i, t}^{\text {miscellaneous }, s} * \text { post }+ \\
& \text { GDP_growth }_{i, t-1}+u_{i, t}^{k s}
\end{aligned}
$$

where crisis is a dummy variable, which is one if the observation is from 2008 to 2012, and is zero otherwise. The post-crisis dummy (post) is one if an observation is from 2013 and onwards, and is zero otherwise. The results are reported in columns (2), (4) and (6) in Table 2 for advanced economies, and the same columns of Table 3 for emerging economies.

\footnotetext{
${ }^{11} \mathrm{We}$ implicitly make the assumption that the substitution and complementarity patterns between the types of capital inflows are taking place during each quarter. This is not a very restrictive assumption due to the aggregate characteristic of our data. Moreover, using lag of the control variables does not alter the conclusions

${ }^{12}$ The coefficient of lag GDP growth, our proxy of borrower country demand, is positive in the case of the private sector and negative in the case of sovereigns. This captures that sovereigns' revenues increase during high GDP growth periods (tax bases are link to the state of the general economy), reducing their borrowing needs. The statistically significant positive sign for the private sector indicate a potential higher demand of external borrowing the economy is performing well, probably capturing better economic prospects. These results are in line with the July 2017's version of Advjiev et al (2017), which now also explores the dynamic and cross sectional patterns in capital flows by banks, corporates and sovereigns vis-à-vis their local business cycles.
} 
Compared to the results of equation (1), we find a few more coefficients that are statistically significant. The relationship between loan and portfolio debt inflows to AE corporates seems to change overtime (column 2 in Table 2). The pre-crisis coefficient for debt is positive and statistically significant, showing that, across countries, an increase in portfolio debt inflows of 1 percent of GDP was correlated with an increase of about 0.3 percent of GDP in loan inflows. Then, this relationship became one of substitution during the crisis period for AE corporates. The addition of the coefficient interacted with the crisis dummy and the non-interacted coefficient is about -0.6 , and jointly statistically significant as indicated by the p-values at the bottom of the table. This is also the case for the post-crisis period (with an overall coefficient of about -0.1$).^{13}$

This finding seems consistent with the literature that was reporting an important decline in international bank cross-border loans within AEs (Forbes et al 2017, Cerutti and Claessens 2017, Cerutti and Zhou 2017) and an increase in debt issuance in many countries (Shin, 2013, Lo Duca et al 2014, Avdjiev et al., 2016). Instead, the substitution relationship in the case of AEs corporates between loans and equity seems to remain throughout the sample but at different intensity within sub-periods. This seems to be also the case for AE sovereigns, where the substitution relationships between loans and portfolio debt inflows remain throughout the sample but at different intensity within sub-periods, and the negative correlations between loans and debt inflows as well as loans and miscellaneous inflows also decreases during the crisis period. The relationships between types of capital inflows for AE banks do not display consistent signs across specifications.

The results for EM corporates (column 2 in Table 3) contrast with the findings for AE corporates. We find that during the crisis and post -crisis period, complementarity patterns emerge between loans and portfolio equity and between loans and portfolio debt. This is in contrast with some degree of substitution between loans and portfolio equity during the precrisis period. This could be consistent with the literature that finds that gross capital inflows to EMs are pro-cyclical, probably driven by external factors that are frequently associated with central countries monetary policy and financial variables (Milesi-Ferretti and Tille 2011, Broner et al 2013, Bruno and Shin 2015b, Cerutti, Claessens, and Ratnovski 2017). Like in the case of AE sovereigns, this complementarity relationship does not seem to be present in the case of EM sovereigns, where the relationship seems to be negative between loans and portfolio debt inflows during the entire sample (see column 6 in Table 3). This probably reflects that the increased funding of sovereigns through debt issuance (abroad or domestic) has been

\footnotetext{
${ }^{13}$ In regressions not shown but available at request, we also find that these patterns are also robust to not including equity and miscellaneous in the regressions, as well as estimating the regressions using loans plus miscellaneous together as dependent variable.
} 
bought by non-residents, resulting also in lower levels of international banks loans to EM sovereigns. ${ }^{14}$

Table 2. Loans Inflows by Borrower Type, Advanced Economies

\begin{tabular}{|c|c|c|c|c|c|c|}
\hline Variables & $\begin{array}{c}1) \\
\text { Loans, } \\
\text { Corporates }\end{array}$ & $\begin{array}{c}(2) \\
\text { Loans, } \\
\text { Corporates }\end{array}$ & $\begin{array}{c}\text { (3) } \\
\text { Loans, } \\
\text { Banks }\end{array}$ & $\begin{array}{c}\text { (4) } \\
\text { Loans, } \\
\text { Banks }\end{array}$ & $\begin{array}{c}\text { (5) } \\
\text { Loans, } \\
\text { Sovereigns }\end{array}$ & $\begin{array}{c}6) \\
\text { Loans, } \\
\text { Sovereigns }\end{array}$ \\
\hline debt & $\begin{array}{l}-0.096 \\
(0.069)\end{array}$ & $\begin{array}{c}0.297^{* * *} \\
(0.097)\end{array}$ & $\begin{array}{c}-0.099 * * \\
(0.039)\end{array}$ & $\begin{array}{l}-0.067 \\
(0.043)\end{array}$ & $\begin{array}{c}-0.277^{* * *} \\
(0.029)\end{array}$ & $\begin{array}{c}-0.239 * * * \\
(0.059)\end{array}$ \\
\hline equity & $\begin{array}{c}-0.119 * * \\
(0.050)\end{array}$ & $\begin{array}{c}-0.208^{* * *} \\
(0.070)\end{array}$ & $\begin{array}{c}0.287 \\
(0.177)\end{array}$ & $\begin{array}{c}0.21 \\
(0.234)\end{array}$ & $\begin{array}{c}0.614 \\
(1.176)\end{array}$ & $\begin{array}{l}-0.737 \\
(5.312)\end{array}$ \\
\hline misc & $\begin{array}{l}-0.061 \\
(0.052)\end{array}$ & $\begin{array}{c}0.180 \\
(0.190)\end{array}$ & $\begin{array}{l}-0.003 \\
(0.024)\end{array}$ & $\begin{array}{c}0.095^{* *} \\
(0.039)\end{array}$ & $\begin{array}{c}-0.148^{* * *} \\
(0.023)\end{array}$ & $\begin{array}{c}-0.369^{* * *} \\
(0.083)\end{array}$ \\
\hline debt*risis & & $\begin{array}{c}-0.870 * * * \\
(0.148)\end{array}$ & & $\begin{array}{l}-0.138 \\
(0.117)\end{array}$ & & $\begin{array}{l}-0.091 \\
(0.070)\end{array}$ \\
\hline debt*postcrisis & & $\begin{array}{c}-0.412^{*} \\
(0.223)\end{array}$ & & $\begin{array}{c}0.03 \\
(0.326)\end{array}$ & & $\begin{array}{l}0.180^{*} \\
(0.103)\end{array}$ \\
\hline equity*crisis & & $\begin{array}{c}0.167 \\
(0.117)\end{array}$ & & $\begin{array}{l}-0.058 \\
(0.392)\end{array}$ & & $\begin{array}{c}1.285 \\
(5.436)\end{array}$ \\
\hline equity*postcrisis & & $\begin{array}{c}0.158 \\
(0.126)\end{array}$ & & $\begin{array}{c}0.4 \\
(2.356)\end{array}$ & & $\begin{array}{c}-0.023 \\
(11.022)\end{array}$ \\
\hline misc*crisis & & $\begin{array}{l}-0.291 \\
(0.198)\end{array}$ & & $\begin{array}{c}-0.170 * * * \\
(0.051)\end{array}$ & & $\begin{array}{c}0.342 * * * \\
(0.089)\end{array}$ \\
\hline misc*postcrisis & & $\begin{array}{c}-0.13 \\
(0.258)\end{array}$ & & $\begin{array}{l}-0.081 \\
(0.098)\end{array}$ & & $\begin{array}{c}0.097 \\
(0.091)\end{array}$ \\
\hline GDP_growth (lag) & $\begin{array}{c}0.182^{* * *} \\
(0.057)\end{array}$ & $\begin{array}{c}0.153^{* * *} \\
(0.056)\end{array}$ & $\begin{array}{l}0.215^{*} \\
(0.113) \\
\end{array}$ & $\begin{array}{l}0.211^{*} \\
(0.113)\end{array}$ & $\begin{array}{c}-0.306^{* * *} \\
(0.052) \\
\end{array}$ & $\begin{array}{c}-0.272^{* * *} \\
(0.051)\end{array}$ \\
\hline Time FE & Yes & Yes & Yes & Yes & Yes & Yes \\
\hline Country FE & Yes & Yes & Yes & Yes & Yes & Yes \\
\hline Observations & 1,061 & 1,061 & 664 & 664 & 908 & 908 \\
\hline R-squared & 0.133 & 0.166 & 0.197 & 0.215 & 0.278 & 0.318 \\
\hline $\begin{array}{l}\text { Joint test (debt, } \\
\text { debt_crisis) } \\
\text { Joint test (debt, } \\
\text { debt_postcrisis) }\end{array}$ & & $\begin{array}{l}0.000 \\
0.008\end{array}$ & & $\begin{array}{l}0.048 \\
0.293\end{array}$ & & $\begin{array}{l}0.000 \\
0.000\end{array}$ \\
\hline
\end{tabular}

Notes: This table reports the regression results for estimating equation (1) and (2) during the period 2003Q1-2016Q1 for advanced economies. "Crisis" dummy is 1 if an observation is between 2008Q1 to 2012Q4, and is 0 otherwise. "Post-Crisis" dummy (post) is 1 if an observation is from 2013Q1 to 2016Q1, and is 0 otherwise. A constant as well as time and borrower country fixed effects were included but they are not reported. Robust standard errors are in parentheses. Asterisks denote significance of coefficients, with $* * *, * * *$ indicating significance at $1 \%, 5 \%$, and $10 \%$ level, respectively. P-values are reported for joint tests.

${ }^{14}$ These results are robust to a specification using lagged variables as controls, instead of contemporaneous ones. 
Table 3. Loans Inflows by Borrower Type, Emerging Economies

\begin{tabular}{|c|c|c|c|c|c|c|}
\hline Variables & $\begin{array}{c}1) \\
\text { Loans, } \\
\text { Corporates }\end{array}$ & $\begin{array}{c}\text { (2) } \\
\text { Loans, } \\
\text { Corporates }\end{array}$ & $\begin{array}{c}\text { (3) } \\
\text { Loans, } \\
\text { Banks } \\
\end{array}$ & $\begin{array}{c}(4) \\
\text { Loans, } \\
\text { Banks } \\
\end{array}$ & $\begin{array}{c}\text { (5) } \\
\text { Loans, } \\
\text { Sovereigns } \\
\end{array}$ & $\begin{array}{c}\text { (6) } \\
\text { Loans, } \\
\text { Sovereigns } \\
\end{array}$ \\
\hline debt & $\begin{array}{c}0.055 \\
(0.069)\end{array}$ & $\begin{array}{l}-0.196 \\
(0.124)\end{array}$ & $\begin{array}{l}-0.047 \\
(0.073)\end{array}$ & $\begin{array}{l}-0.078 \\
(0.093)\end{array}$ & $\begin{array}{c}-0.179 * * * \\
(0.030)\end{array}$ & $\begin{array}{c}-0.219^{* * *} \\
(0.050)\end{array}$ \\
\hline equity & $\begin{array}{c}0.013 \\
(0.064)\end{array}$ & $\begin{array}{c}-0.182^{* *} \\
(0.084)\end{array}$ & $\begin{array}{c}0.006 \\
(0.109)\end{array}$ & $\begin{array}{c}0.005 \\
(0.111)\end{array}$ & $\begin{array}{l}-73.666 \\
(97.942)\end{array}$ & $\begin{array}{c}-34.443 \\
(170.611)\end{array}$ \\
\hline misc & $\begin{array}{l}-0.017 \\
(0.038)\end{array}$ & $\begin{array}{c}0.035 \\
(0.073)\end{array}$ & $\begin{array}{l}-0.012 \\
(0.028)\end{array}$ & $\begin{array}{l}-0.001 \\
(0.038)\end{array}$ & $\begin{array}{c}-0.189 * * * \\
(0.027)\end{array}$ & $\begin{array}{l}-0.037 \\
(0.063)\end{array}$ \\
\hline debt*crisis & & $\begin{array}{c}0.369 * * \\
(0.171)\end{array}$ & & $\begin{array}{c}0.067 \\
(0.157)\end{array}$ & & $\begin{array}{l}-0.028 \\
(0.069)\end{array}$ \\
\hline debt*postcrisis & & $\begin{array}{c}0.377^{* *} \\
(0.162)\end{array}$ & & $\begin{array}{c}0.269 \\
(0.534)\end{array}$ & & $\begin{array}{c}0.158^{* *} \\
(0.073)\end{array}$ \\
\hline equity*crisis & & $\begin{array}{c}0.499 * * * \\
(0.139)\end{array}$ & & $\begin{array}{c}0.295 \\
(0.619)\end{array}$ & & $\begin{array}{c}-52.465 \\
(203.745)\end{array}$ \\
\hline equity*postcrisis & & $\begin{array}{l}0.435^{* *} \\
(0.204)\end{array}$ & & $\begin{array}{c}-0.684 \\
(1.107)\end{array}$ & & \\
\hline misc*crisis & & $\begin{array}{l}-0.027 \\
(0.098)\end{array}$ & & $\begin{array}{l}-0.025 \\
(0.062)\end{array}$ & & $\begin{array}{c}-0.196 * * * \\
(0.073)\end{array}$ \\
\hline misc*postcrisis & & $\begin{array}{l}-0.108 \\
(0.095)\end{array}$ & & $\begin{array}{l}-0.026 \\
(0.129)\end{array}$ & & $\begin{array}{c}-0.173^{* *} \\
(0.080)\end{array}$ \\
\hline GDP_growth (lag) & $\begin{array}{c}0.034^{* * *} \\
(0.011)\end{array}$ & $\begin{array}{c}0.030 * * * \\
(0.011)\end{array}$ & $\begin{array}{c}0.096^{* * *} \\
(0.024)\end{array}$ & $\begin{array}{c}0.094^{* * *} \\
(0.024)\end{array}$ & $\begin{array}{c}-0.070^{* * *} \\
(0.018) \\
\end{array}$ & $\begin{array}{c}-0.074 * * * \\
(0.018)\end{array}$ \\
\hline $\begin{array}{l}\text { Time FE } \\
\text { Country FE } \\
\text { Observations } \\
\text { R-squared } \\
\end{array}$ & $\begin{array}{c}\text { Yes } \\
\text { Yes } \\
1,094 \\
0.286 \\
\end{array}$ & $\begin{array}{c}\text { Yes } \\
\text { Yes } \\
1,094 \\
0.302 \\
\end{array}$ & $\begin{array}{c}\text { Yes } \\
\text { Yes } \\
957 \\
0.245 \\
\end{array}$ & $\begin{array}{c}\text { Yes } \\
\text { Yes } \\
957 \\
0.246 \\
\end{array}$ & $\begin{array}{c}\text { Yes } \\
\text { Yes } \\
1,071 \\
0.187 \\
\end{array}$ & $\begin{array}{c}\text { Yes } \\
\text { Yes } \\
1,071 \\
0.199 \\
\end{array}$ \\
\hline $\begin{array}{l}\text { Joint test (debt, } \\
\text { debt_crisis) } \\
\text { Joint test (debt, } \\
\text { debt_postcrisis) }\end{array}$ & & $\begin{array}{l}0.097 \\
0.065\end{array}$ & & $\begin{array}{l}0.701 \\
0.660\end{array}$ & & $\begin{array}{l}0.000 \\
0.000\end{array}$ \\
\hline
\end{tabular}

Notes: This table reports the regression results for estimating equation (1) and (2) during the period 2003Q1-2016Q1 for advanced economies. "Crisis" dummy is 1 if an observation is between 2008Q1 to 2012Q4, and is 0 otherwise. "Post-Crisis" dummy (post) is 1 if an observation is from 2013Q1 to 2016Q1, and is 0 otherwise. A constant as well as time and borrower country fixed effects were included but they are not reported. Robust standard errors are in parentheses. Asterisks denote significance of coefficients, with $* * *, * *, *$ indicating significance at $1 \%, 5 \%$, and $10 \%$ level, respectively. P-values are reported for joint tests.

\section{Robustness of the complementarity/substitution relationships}

The previous estimations have been based on estimating equations (1) and (2), which have the inflow of loans to each sector as the dependent variable. Table 4 summarizes the results for AEs of changing the dependent variable in equation (2), first loans, then debt securities, and then equity. The AE relationship between loans and debt securities as captured in Table 2 is 
reflected in raw (1) of Table 4. The same relationship but estimating now debt securities inflows as the dependent variable is presented in raw (4). The results for the statistically significant relationships (reflected in bold in Table) are exactly the same for the pre-crisis and crisis periods: A complementarity relationship exists between loans and debt inflows before the crisis for corporates, then it switches to substitution during the crisis. The relationship for AEs' sovereigns is consistently of substitution. The relationship between loan and equity inflows are reflected in rows (2) and (7), and securities and equity in rows (5) and (8). They are similar across specifications but not as robust as in the case of loans and debt securities. Table 5 summarizes the results for EMs. As in the case of AEs, the relationship between loans and debt EM inflows are very robust to the switching the dependent variable in equation (2). ${ }^{15}$

\section{Table 4. Complementarity and Substitution Relationships, Advanced Economies}

\begin{tabular}{l|ccc} 
& \multicolumn{3}{|c}{ Loans } \\
\hline & Corporates & Banks & Sovereigns \\
\hline (1) Debt & $+/-/-$ & $-/-/-$ & $-/-/-$ \\
(2) Equity & $-/-/-$ & $+/+/+$ & $-/+/-$ \\
(3) Miscellaneous & $+/-/+$ & $+/-/+$ & $-/-/-$
\end{tabular}

\begin{tabular}{l|ccc} 
& \multicolumn{3}{|c}{ Debt } \\
\hline (4) Loans & Corporates & Banks & Sovereigns \\
\hline (5) Equity & $+/-/+$ & $-/-/+$ & $-/-/-$ \\
(6) Miscellaneous & $+/-/-$ & $+/+/+$ & $-/-/+$ \\
& $-/-/-$ & $-/+/+$ & $-/-/-$
\end{tabular}

\begin{tabular}{l|ccc} 
& \multicolumn{3}{|c}{ Equity } \\
\hline (7) Loans & Corporates & Banks & Sovereigns \\
(8) Debt & $-/+/-$ & $+/-/+$ & $-/+/+$ \\
(9) Miscellaneous & $+/-/-$ & $+/+/-$ & $-/-/-$ \\
& $+/-/-$ & $+/-/-$ & $-/+/+$
\end{tabular}

Notes: This table summarizes the sign and the statistical significance between assets by borrower type. Each cell has three signs: the first sign represents the relationship between two instruments for a specific borrower before the crisis, the second cell during the crisis period and the third during the post-crisis period. Red represents 'positive correlation' with statistically significance, green represents 'negative correlation' with significance and black represents 'no statistical significance' between the two instruments, respectively.

\footnotetext{
${ }^{15}$ In the case of EMs, it is not always possible to get estimates for coefficients for equity inflows to the sovereign sector due to the lack of variability of those series.
} 
Table 5. Complementarity and Substitution Relationships, Emerging Economies

\begin{tabular}{l|ccc} 
& \multicolumn{3}{|c}{ Loans } \\
\hline & Corporates & Banks & Sovereigns \\
\hline (1) Debt & $-/+/+$ & $-/-/+$ & $-/-/-$ \\
(2) Equity & $-/+/+$ & $+/+/-$ & $-/-/ N A$ \\
(3) Miscellaneous & $+/+/-$ & $-/-/-$ & $-/-/-$
\end{tabular}

\begin{tabular}{l|ccc} 
& \multicolumn{3}{|c}{ Debt } \\
\hline (4) Loans & Corporates & Banks & Sovereigns \\
\hline (5) Equity & $-/+/+$ & $-/+/+$ & $-/-/-$ \\
(6) Miscellaneous & $+/+/+$ & $+/+/+$ & $-/-/$ NA \\
& $+/-/+$ & $+/-/+$ & $-/-/-$
\end{tabular}

\begin{tabular}{l|ccc} 
& \multicolumn{3}{|c}{ Equity } \\
\hline (7) Loans & Corporates & Banks & Sovereigns \\
(8) Debt & $-/+/+$ & $+/+/-$ & NA \\
(9) Miscellaneous & $+/-/+$ & $+/+/+$ & NA \\
& $-/+/-$ & $-/-/-$ & NA
\end{tabular}

Notes: This table summarizes the sign and the statistical significance between assets by borrower type. Each cell has three signs: the first sign represents the relationship between two instruments for a specific borrower before the crisis, the second cell during the crisis period and the third during the post-crisis period. Red represents 'positive correlation' with statistically significance, green represents 'negative correlation' with significance and black represents 'no statistical significance' between the two instruments, respectively.

\section{Are these Relationships driven by Negative Or Positive Gross Inflows?}

The results presented in the previous section indicate that there are some significant complementary and substitution relationships between types of flows for specific borrowers. Nonetheless, we have not explored so far how these relationships change, taking into consideration the direction of capital flows. For example, do the complementarity relationships capture non-resident declines in the lending or an increase in their lending? Which asset is being substituted in the case of substitute relationships? Focusing on portfolio debt securities and loans, which account for most statistically significant relationships, this section sheds light on these questions.

To address these questions, we further augment equation (2) by allowing that the coefficient of the relationships of loans vis-à-vis debt securities flows can be different in the case of positive inflows and negative inflows (outflows) during the various periods under analysis. Specifically, we include an additional interactive dummy (outflow) which is equal to one when inflows are negative (outflows in the sense that non-residents are reducing their lending), as follows: 


$$
\begin{aligned}
& \text { Inflow }_{i, t}^{\text {Loans }, s}=\alpha_{i}+\alpha_{t}+\beta_{1} \text { Inflow }_{i, t}^{\text {debt }, s}+\beta_{1}{ }_{1} \text { Inflow }_{i, t}^{\text {debt }, s} * \text { outflow }+\gamma_{1} \text { Inflow }_{i, t}^{\text {debt }, s} * \text { crisis } \\
& +\gamma^{\prime}{ }_{1} \text { Inflow }_{i, t}^{\text {debt }, s} * \text { crisis } * \text { outflow }+\theta_{1} \text { Inflow }_{i, t}^{\text {debt }, s} * \text { post }+\theta^{\prime}{ }_{1} \text { Inflow }_{i, t}^{\text {debt }, s} * \text { post } \\
& * \text { ouflow }+\beta_{2} \text { Inflow }_{i, t}^{\text {equity,s }}+\beta_{3} \text { Inflow }_{i t}^{\text {miscellaneous }, s}+\gamma_{2} \text { Inflow }_{i, t}^{\text {equity }, s} * \text { crisis } \\
& +\gamma_{3} \text { Inflow }_{i, t}^{\text {miscellaneous }, s} * \text { crisis }+\theta_{2} \text { Inflow }_{i, t}^{\text {equity }, s} * \text { post }+\theta_{3} \text { Inflow }_{i, t}^{\text {miscellaneous }, s} \\
& * \text { post }+ \text { GDP_growth }_{i, t-1}+u_{i, t}^{k s}
\end{aligned}
$$

Table 6. Loans Inflows by Borrower Type, Direction of Flows, Advanced Economies

\begin{tabular}{|l|c|c|c|c|c|c|}
\hline \multicolumn{1}{|c|}{ Variables } & $\begin{array}{c}(1) \\
\text { Loans, }\end{array}$ & $\begin{array}{c}(2) \\
\text { Loans, }\end{array}$ & $\begin{array}{c}(3) \\
\text { Loans, }\end{array}$ & $\begin{array}{c}(4) \\
\text { Loans, }\end{array}$ & $\begin{array}{c}(5) \\
\text { Loans, }\end{array}$ & $\begin{array}{c}(6) \\
\text { Loans, }\end{array}$ \\
\hline debt & $0.297^{* * *}$ & $0.288^{* *}$ & -0.067 & 0.023 & $-0.239^{* * *}$ & $-0.129^{*}$ \\
debt*outflow & $(0.097)$ & $(0.117)$ & $(0.043)$ & $(0.044)$ & $(0.059)$ & $(0.078)$ \\
& & -0.198 & & $-1.494^{* * *}$ & & -0.236 \\
debt*risis & & $(0.365)$ & & $(0.239)$ & & $(0.165)$ \\
& $-0.870^{* * *}$ & $-1.205^{* * *}$ & -0.138 & 0.085 & -0.091 & 0.143 \\
debt*outflow*crisis & $(0.148)$ & $(0.185)$ & $(0.117)$ & $(0.177)$ & $(0.070)$ & $(0.089)$ \\
& & $1.132^{* *}$ & & $0.879^{* *}$ & & $-0.737^{* * *}$ \\
debt*postcrisis & & $(0.446)$ & & $(0.349)$ & & $(0.182)$ \\
& $-0.412^{*}$ & $-0.535^{*}$ & 0.03 & -0.114 & $0.180^{*}$ & 0.152 \\
debt*outflow*postcrisis & $(0.223)$ & $(0.298)$ & $(0.326)$ & $(0.513)$ & $(0.103)$ & $(0.133)$ \\
& & 0.503 & & $1.604^{*}$ & & -0.077 \\
GDP_growth (lag) & & $(0.583)$ & & $(0.915)$ & & $(0.269)$ \\
& $0.153^{* * *}$ & $0.140^{* *}$ & $0.211^{*}$ & 0.163 & $-0.272^{* * *}$ & $-0.164^{* * *}$ \\
Time FE & $(0.056)$ & $(0.057)$ & $(0.113)$ & $(0.110)$ & $(0.051)$ & $(0.049)$ \\
Country FE & Yes & Yes & Yes & Yes & Yes & Yes \\
Other flows & Yes & Yes & Yes & Yes & Yes & Yes \\
Observations & Yes & Yes & Yes & Yes & Yes & Yes \\
R-squared & 1,061 & 1,061 & 664 & 664 & 908 & 908 \\
\hline
\end{tabular}

Notes: This table reports the regression results for estimating equation (2) and (3) during the period 2003Q1-2016Q1 for advanced economies. "Crisis" dummy is 1 if an observation is between 2008Q1 to 2012Q4, and is 0 otherwise. "Post-Crisis" dummy (post) is 1 if an observation is from 2013Q1 to 2016Q1, and is 0 otherwise. "outflow" dummy is 1 if negative debt inflows during a period, and is 0 otherwise. A constant, equity and miscellaneous flows as well as time and borrower country fixed effects were included but they are not reported. Robust standard errors are in parentheses. Asterisks denote significance of coefficients, with $* * *, * *, *$ indicating significance at $1 \%, 5 \%$, and $10 \%$ level, respectively.

The results are shown in Table 6 and 7 for AEs and EMs, respectively. They show that the statistically significant complementarity or substitution relationships found in the previous section were mostly present when there was an increase in non-residents debt securities flows. For example, AE corporates' complementary relationship before the crisis between debt securities and loans was driven by increases in both types of instruments (see Table 6; the positive sign for debt in column (1) is driven by the interacted variable debt*outflow in column (2)). Similarly, the substitution relationships of AE corporates since the crisis as well as AE sovereigns were driven by an increase in debt securities which were partially replacing international banks' loans. An exception for AEs seems to be the larger substitution relationship during the crisis for AE sovereigns, when an increase in cross-border loans partially replaced debt financing on average. 
Table 7. Loans Inflows by Borrower Type, Direction of Flows, Emerging Markets

\begin{tabular}{|l|c|c|c|c|c|c|}
\hline \multicolumn{1}{|c|}{ Variables } & $\begin{array}{c}(1) \\
\text { Loans, } \\
\text { Corporates }\end{array}$ & $\begin{array}{c}(2) \\
\text { Loans, } \\
\text { Corporates }\end{array}$ & $\begin{array}{c}(3) \\
\text { Loans, } \\
\text { Banks }\end{array}$ & $\begin{array}{c}(4) \\
\text { Loans, } \\
\text { Banks }\end{array}$ & $\begin{array}{c}(5) \\
\text { Loans, } \\
\text { Sovereigns }\end{array}$ & $\begin{array}{c}(6) \\
\text { Loans, } \\
\text { Sovereigns }\end{array}$ \\
\hline debt & -0.196 & $-0.361^{* *}$ & -0.078 & 0.147 & $-0.219^{* * *}$ & $-0.316^{* * *}$ \\
debt*outflow & $(0.124)$ & $(0.151)$ & $(0.093)$ & $(0.134)$ & $(0.050)$ & $(0.060)$ \\
& & $0.663^{*}$ & & $-0.668^{* *}$ & & $0.513^{* * *}$ \\
debt*risis & & $(0.358)$ & & $(0.285)$ & & $(0.173)$ \\
& $0.369^{* *}$ & $0.501^{* *}$ & 0.067 & -0.267 & -0.028 & $0.214^{* * *}$ \\
debt*outflow*crisis & $(0.171)$ & $(0.196)$ & $(0.157)$ & $(0.235)$ & $(0.069)$ & $(0.078)$ \\
& & -0.463 & & $0.841^{* *}$ & & $-1.520^{* * *}$ \\
debt*postcrisis & & $(0.612)$ & & $(0.386)$ & & $(0.231)$ \\
& $0.377^{* *}$ & $0.427^{* *}$ & 0.269 & -0.182 & $0.158^{* *}$ & $0.176^{* *}$ \\
debt*outflow*postcrisis & $(0.162)$ & $(0.194)$ & $(0.534)$ & $(0.778)$ & $(0.073)$ & $(0.085)$ \\
& & -0.22 & & 1.156 & & -0.039 \\
GDP_growth (lag) & & $(0.446)$ & & $(1.264)$ & & $(0.253)$ \\
& $0.030^{* * *}$ & $0.029^{* *}$ & $0.094^{* * *}$ & $0.089^{* * *}$ & $-0.074^{* * *}$ & $-0.076^{* * *}$ \\
Time FE & $(0.011)$ & $(0.011)$ & $(0.024)$ & $(0.024)$ & $(0.018)$ & $(0.018)$ \\
Country FE & Yes & Yes & Yes & Yes & Yes & Yes \\
Other flows & Yes & Yes & Yes & Yes & Yes & Yes \\
Observations & Yes & Yes & Yes & Yes & Yes & Yes \\
R-squared & 1,094 & 1,094 & 957 & 957 & 1,071 & 1,071 \\
\end{tabular}

Notes: This table reports the regression results for estimating equation (2) and (3) during the period 2003Q1-2016Q1 for emerging markets. "Crisis" dummy is 1 if an observation is between 2008Q1 to 2012Q4, and is 0 otherwise. "Post-Crisis" dummy (post) is 1 if an observation is from 2013Q1 to 2016Q1, and is 0 otherwise. "outflow" dummy is 1 if negative debt inflows during a period, and is 0 otherwise. A constant, equity and miscellaneous flows as well as time and borrower country fixed effects were included but they are not reported. Robust standard errors are in parentheses. Asterisks denote significance of coefficients, with $* * *, * * *$ indicating significance at $1 \%, 5 \%$, and $10 \%$ level, respectively.

In the case of EMs, the results in Table 7 indicate that the complementary relationships experienced by EM corporates since the crisis reflect an increase in both debt securities and loan borrowing. Although not statistically significant in column (3), the EM banks' complementarity relationship seems to have been driven by an outflow of both debt securities and loans during the crisis (column 4). Like the case of AEs, the overall substitution relationship in the case of EMs' sovereigns is reflecting an increase in borrowing through debt securities, which are partially replacing international banks' loans.

\section{ARe THERE COMmon DYNAMics Driving THE RElationships?}

The results presented in the previous sections seem to indicate that some of the relationships between types of flows for specific borrowers could be the result of common dynamics in capital inflows across countries (e.g. EM corporates increase in borrowing through both debt securities and loans since the crisis). This section analyzes this possibility with a more rigorous 
approach, namely, through a dynamic latent factor model. We first present the methodology used and then the results.

\subsection{Calculation of Factors}

To extract instrument-specific common dynamics of capital inflows across countries and across borrower types, we use dynamic latent factor models using Bayesian techniques introduced by Kose et al. (2003). ${ }^{16}$ For each instrument of capital inflow, we estimate this model separately for a set of advanced economies (22 countries) and emerging economies (23 countries). Let $y_{i, t}^{f, s}$ be the capital inflow as a share of GDP for country $i \quad(\mathrm{i}=1,2, \ldots, \mathrm{N}, \mathrm{N}=22$ if advanced economies and $\mathrm{N}=23$ if emerging economies), quarter $t(\mathrm{t}=1,2, \ldots 53)$ of instrument, $k$, and borrower type, $s$. An instrument $(k)$ can take four types, \{portfolio debt, portfolio equity, loans, miscellaneous . A borrower type $(s)$ can take three types, \{banks, corporate, sovereign . The dynamic latent factor model is given by

$$
y_{i, t}^{k, s}=\beta_{i}^{k, g l o b a l} f_{t}^{k, g l o b a l}+\beta_{i}^{k, s} f_{t}^{k, s}+\varepsilon_{i, t}^{k, s}
$$

where $f_{t}^{k, g l o b a l}$ is a time-varying global (common) factor for an inflow type $k$ and $f_{t}^{k, s}$ is a time-varying borrower-specific subfactor for each borrower type $s$. The first factor, $f_{t}^{k, g l o b a l}$, is common across all instrument $\mathrm{k}$-type capital flows for $\mathrm{N}$ countries. The second factor, $f_{t}^{k, s}$, is common to all capital inflows for an instrument $k$ and a borrower type $s$. The factor loadings, $\beta_{i}^{k, g l o b a l}$ and $\beta_{i}^{k, s}$ measure the responses of an individual country's capital inflow to changes in the global and borrower-specific subfactors, respectively. Finally, $\varepsilon_{i, t}^{k, s}$, is the countryspecific or idiosyncratic component of each country's capital inflow, which captures purely national movements of capital inflow.

We assume $\varepsilon_{i, t}^{k, s}, f_{t}^{k, g l o b a l}$ and $f_{t}^{k, s}$ to follow autoregressive (AR) processes, which in turn allows (4) to be a dynamic latent factor model. Each idiosyncratic term follows an $\operatorname{AR}(p)$ process as follows:

$$
\varepsilon_{i, t}^{k, s}=\rho_{i, 1} \varepsilon_{i, t-1}^{k, s}+\rho_{i, 2} \varepsilon_{i, t-2}^{k, s}+\cdots+\rho_{i, p} \varepsilon_{i, t-p}^{k, s}+u_{i, t}
$$

where $u_{i, t} \sim N\left(0, \sigma_{i}^{2}\right)$ and $\mathrm{E}\left(u_{i, t} u_{i, t-s}\right)=0$ for $\mathrm{s} \neq 0$. For the global factor and borrowerspecific subfactors, we assume that the factors follow $\operatorname{AR}(\mathrm{q})$ processes as follows:

$$
\begin{array}{r}
f_{t}^{k, \text { global }}=\rho_{1}^{k, \text { global }} f_{t-1}^{k, \text { global }}+\cdots+\rho_{q}^{k, \text { global }} f_{t-q}^{k, \text { global }}+u_{t}^{k, \text { global }} \\
f_{t}^{k, s}=\rho_{1}^{k, s} f_{t-1}^{k, s}+\rho_{2}^{k, s} f_{t-2}^{k, s}+\cdots+\rho_{q}^{k, s} f_{t-q}^{k, s}+u_{t}^{k, s}(7)
\end{array}
$$

\footnotetext{
${ }^{16}$ See Neely and Rapach (2011) and Cerutti et al. (2015), for example, for applications of this methodology.
} 
where $u_{t}^{f, g l o b a l} \sim N\left(0, \sigma_{\text {global }}^{2}\right), u_{t}^{k, s} \sim N\left(0, \sigma_{k, s}^{2}\right)$ and $\mathrm{E}\left(u_{t}^{f, g l o b a l} u_{t-j}^{f, g l o b a l}\right)=E\left(u_{t}^{k, s} u_{t-j}^{k, s}\right)=$ 0 for $\mathrm{j} \neq 0$.

The latent nature of the factors in (4) does not allow for the standard common regression methods to estimate the model. Thus, we rely on Bayesian techniques as in Kose, Otrok and Whiteman (2003) to estimate the model. As pointed out by Kose et al. (2003), Bayesian procedures efficiently handle large cross sections of data and a large number of factors in dynamic factor models. Bayesian estimation includes a step where one simulates draws from the complete posterior distribution for the model parameters and factors by successively drawing from a series of conditional distributions using a Markov chain Monte Carlo (MCMC) procedure. Posterior distribution properties for the model parameters are based on 200,0000 MCMC replications after 20,000 burn-in replications.

Before the drawing from a posterior distribution, we normalize the sign of the factor/loadings as neither the signs nor scales of the factors and factor loadings are separately identified in (4). We follow a strategy similar to Kose et al. (2003) by restricting the loadings on the global factor for the first country in our sample to be positive and by restricting the loadings on the borrower-specific subfactor for one country in each subfactor to be positive. Second, we assume that each of the factor variances to be equal to 1 , thereby, normalizing the scales of each factor.

To implement Bayesian techniques, we use the following conjugate priors to estimate the model:

$$
\begin{aligned}
& \left(\beta_{i}^{k, g l o b a l}, \beta_{i}^{k, s}\right)^{\prime} \sim N\left(0, I_{2}\right) \\
& \left(\rho_{i, 1}, \rho_{i, 2}, \ldots, \rho_{i, p}\right)^{\prime} \sim N\left[0, \operatorname{diag}\left(1,0.5, \ldots, 0.5^{p}\right)\right](\mathrm{i}=1,2, \ldots \mathrm{N}) \\
& \left(\rho_{1}^{k, \text { global }}, \rho_{2}^{k, g l o b a l}, \ldots, \rho_{q}^{k, g l o b a l}\right)^{\prime} \sim N\left[0, \operatorname{diag}\left(1,0.5, \ldots, 0.5^{q}\right)\right] \\
& \left(\rho_{1}^{k, s}, \rho_{2}^{k, s}, \ldots, \rho_{q}^{k, s}\right)^{\prime} \sim N\left[0, \operatorname{diag}\left(1,0.5, \ldots, 0.5^{q}\right)\right] \\
& \left(\sigma_{j}^{2}\right)^{\prime} \sim I G(6,0.001)
\end{aligned}
$$

where IG in equation (12) refers to the inverse-gamma distribution. Assumptions from (9) to (11) imply that the prior distributions for the AR parameters decay as the lag length increases and become more tightly centered on zero. We also assume that the AR processes in (5) to (7) are stationary. In practice, we set the length of both idiosyncratic and factor auto-regressive polynominals to 2 . The results are robust to other non-zero values of $\mathrm{p}$ and $\mathrm{q}$.

\subsection{Global factor and borrower-specific subfactors}

The means for the posterior distributions of the AE global factors is presented in Figure 8.1 for each instrument type. It is possible to observe some commonality across AE borrowers in 
terms of portfolio debt and equity inflows during the pre-crisis and the peak of the crisis in 2008. The global common factor captures inflows across countries during the pre-crisis period, and fluctuations in common stance during the crisis and post-crisis period. There is also some amplitude of co-movement in the case of other investment loans and miscellaneous instruments, with its global common factors showing an increase during the peak of the global financial crisis, probably reflecting how borrowers turned to non-traditional borrowing during that time. AE borrower-type common subfactors, which are estimated controlling by the global factor in the type of instrument, are shown in Figure 8.2 for each borrower. Here, it is possible to appreciate the heterogeneity across sectors. For example, while AE sovereigns seem to have higher common debt inflows during the pre-crisis period than AE corporates and banks, the opposite seems to be happening with respect to the loan inflow subfactor.

EM global factors and borrower-specific subfactors are presented in Figure 9.1 and 9.2, respectively. Figure 9.1 shows that there is more common variability in the evolution of the global common factor of portfolio debt and miscellaneous instruments during the crisis, implying that the sharp declines in some types of capital inflows were common across emerging economies. The flat EM global factor for loan and equity inflows, suggestive of heterogeneity across borrowers. ${ }^{17}$ Subfactors for loans in Figure 9.2 provide some insight, the subfactor for loans to banks is much more volatile than in the case of EM sovereign and corporates.

Figure 8.1. Common Factors by Instruments, Advanced Economies

\section{Common Factors by Instruments: Advanced Economies}

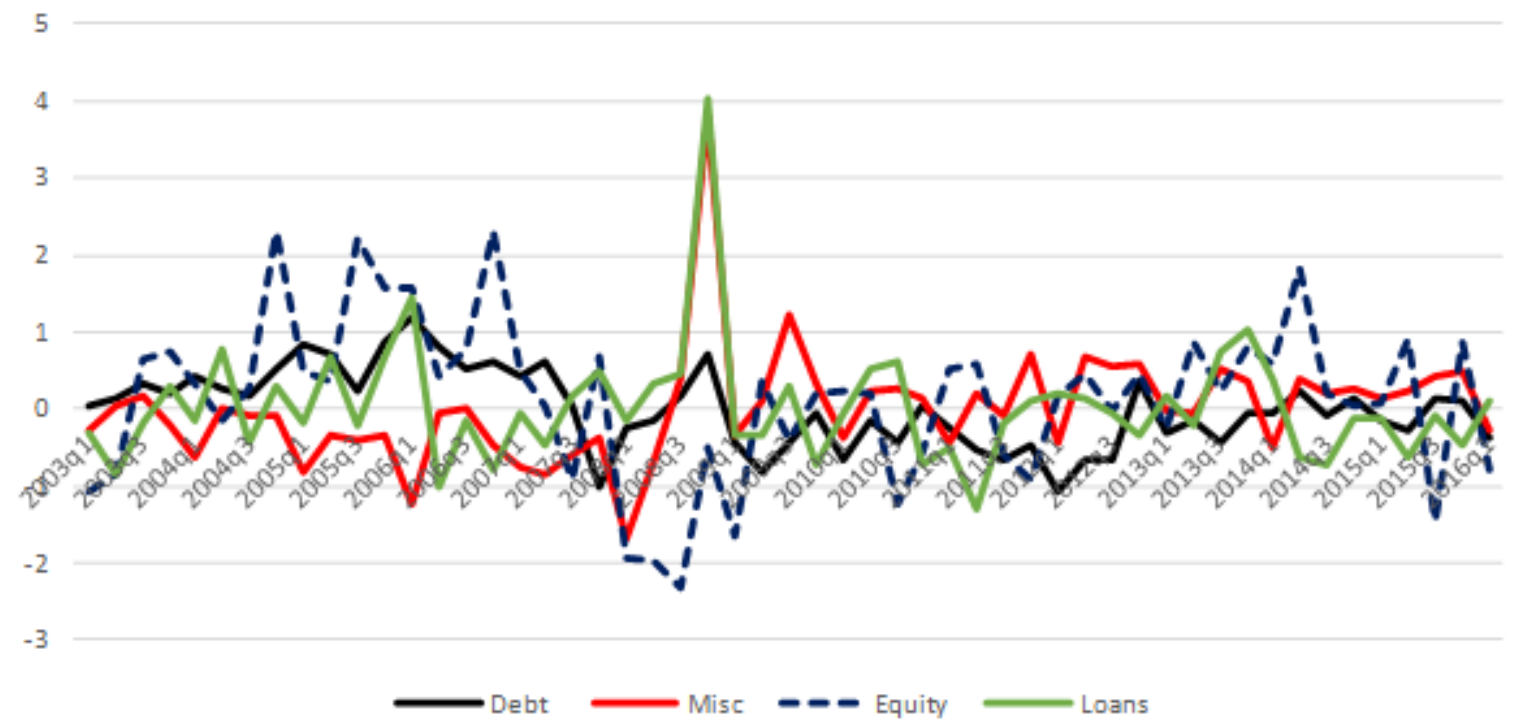

\footnotetext{
17 The results found in the literature (e.g., Cerutti et al 2015) which would indicate a high co-movement in international bank flows towards EMs do not contradict our findings. These studies do not break down 'other investments' into loans and miscellaneous instruments. From our results, it is clear that their findings are driven by the co-movement across countries in miscellaneous instruments.
} 
Figure 8.2. Subfactors by instruments and borrowers, Advanced Economies
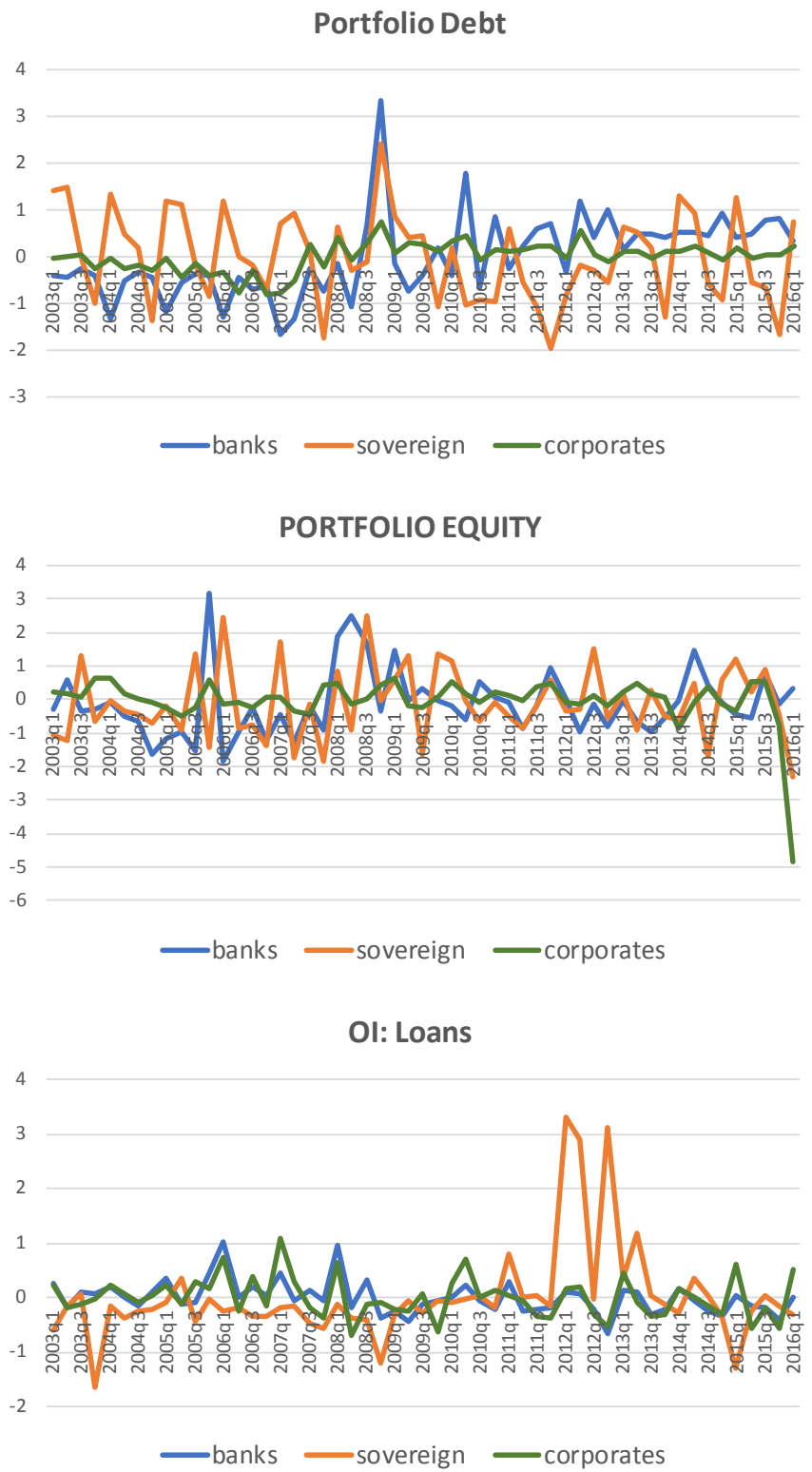

OI: Miscellaneous

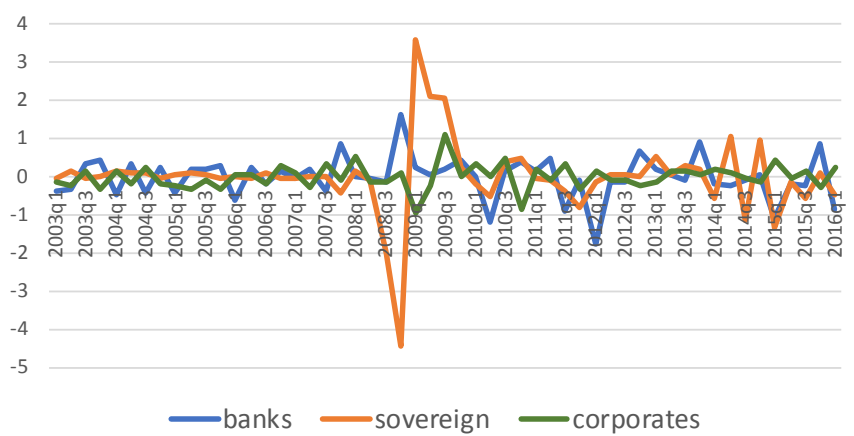


Figure 9.1. Common Factors by Instruments, Emerging Economies

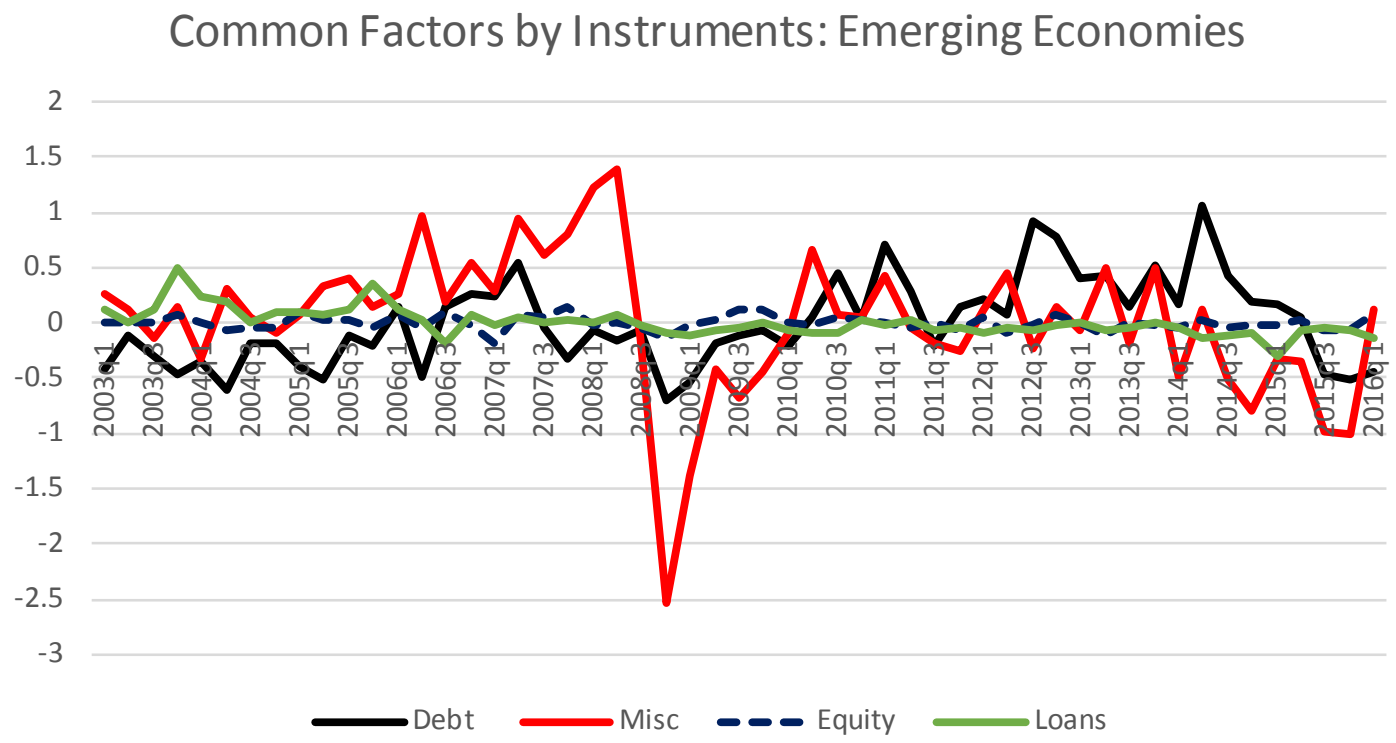

Figure 9.2. Subfactors by Instruments and Borrowers, Emerging Economies

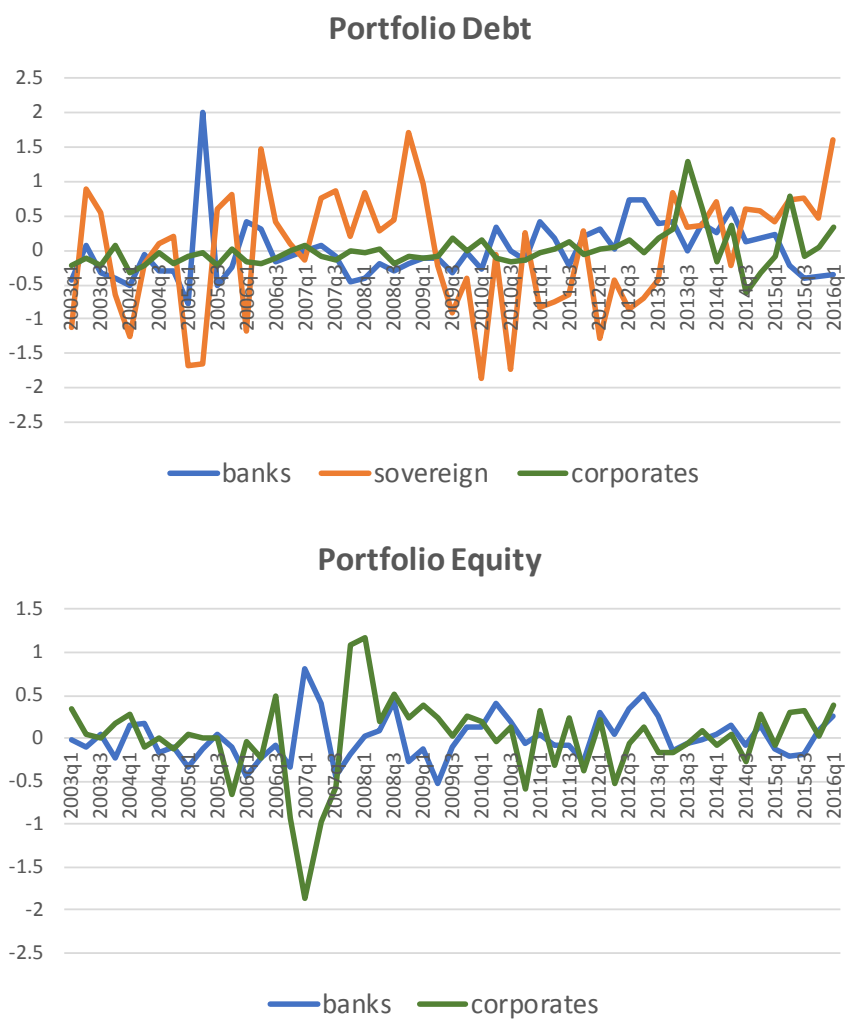




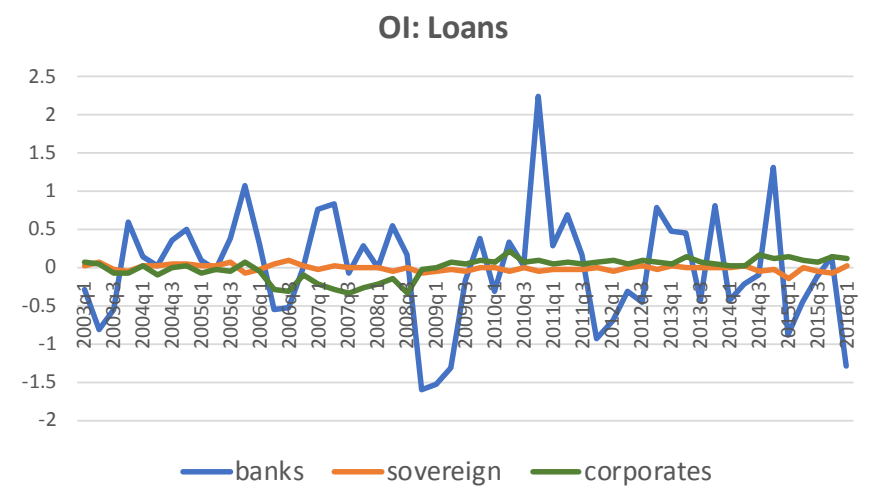

OI: Miscellaneous

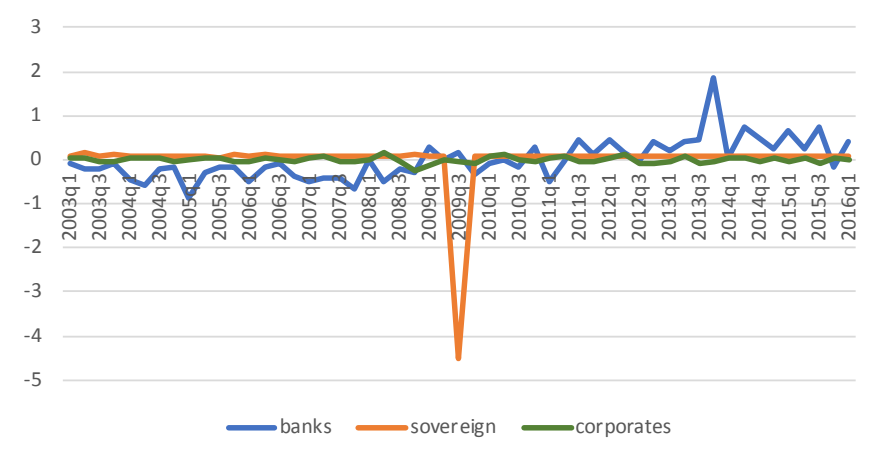

\subsection{Disentangling the role of common and idiosyncratic factors}

In this section, we quantify the extent to which the factors, common global and subfactors together, explain the borrowing patterns across the different countries. Put differently, how much can a country's capital inflow be explained by some common co-movements across instrument type and across borrower type versus by country-specific idiosyncratic components?

To test this idea, we use the estimated factors and the corresponding factor loadings for the global factor and individual country-borrower type factor loadings from equation (4). We decompose a capital flow series into two components: first, predicted values implying that the values that can be explained by the global factor and borrower-type subfactor, and second, the residual, which refers to a part of capital inflows that reflects a pure country-specific component. For the first part, we use the estimated-country specific-factor loadings, $\hat{\beta}_{i}^{k, g l o b a l}$ and $\hat{\beta}_{i}^{k, s}$ and construct the 'predicted' inflows by multiplying the factor loadings with corresponding factors as follows, Inflow_Predicted $d_{i, t}^{k . s}=\hat{\beta}_{i}^{k, g l o b a l} f_{t}^{k, g l o b a l}+\hat{\beta}_{i}^{k, s} f_{t}^{k, s}$. This predicted component corresponds to what is commonly associated as the result of the global financial cycle or push factors in the literature. The second part, 'residual', is constructed as the difference between the actual flow and the predicted value, as Inflow_Residuals $s_{i, t}^{k, s}=$ $\hat{\varepsilon}_{i, t}^{k, s}=y_{i, t}^{k, s}-\left(\hat{\beta}_{i}^{k, g l o b a l} f_{t}^{k, g l o b a l}+\hat{\beta}_{i}^{k, s} f_{t}^{k, s}\right)$. 
With these variables, we run the same regression as in section III, replacing the countryspecific inflows with predicted value and residuals. Our baseline specification is as follows:

$$
\operatorname{Inflow}_{i, t}^{\text {Loans,s }}=\alpha_{i}+\alpha_{t}+\lambda_{1}(\text { Inflow_Predicted })_{i, t}^{k, s}+\lambda_{2}(\text { Inflow_Residuals })_{i, t}^{k, s}+u_{i, t}^{k, s}
$$

where $\mathrm{k}$ can be three instrument types other than loans. Columns (1), (3) and (5) of Table 8 reports the results for the advanced economies and the same columns of Table 9 reports the results for the emerging economies.

For the advanced economies, the negative coefficients of residuals-the part of inflow not explained by common factors-in sovereign borrowing in loans (column (5)) highlight the importance of country-specific components, rather than common movements across countries captured by the common factors. For corporates, substitution is present between corporate borrowing in loans and debt residuals as well as equity residuals throughout the sample period. For sovereign borrowing, the previously found substitution relationship between loans and debt inflows through the estimation sample (see Table 2 ) is captured by the residual variable. Similarly, the substitution between loans and miscellaneous, is also captured by the residuals of miscellaneous type, but the predicted part of miscellaneous inflows is also negative and statistically significant, signaling that some part of the substitution was also driven by common trends across AEs.

Columns (1), (3) and (5) of Table 9 show results for the emerging economies. In the case of inflows to EM sovereigns, the previously found substitution relationship between loans and debt through the sample period (Table 3 ) seems to be the results of both predicted and residual variables. This does not seem to be the case of the substitution relationship between loans and miscellaneous, which is driven by the residual factor.

We further augment the specification of equation (13) with crisis and post-crisis dummies, analogous to equation (2) in section III, to understand how the patterns of international capital flows have changed since the crisis. The results are reported in columns (2), (4) and (6) of Table 8. For AE sovereigns, the residuals (country-specific components unexplained by global and subfactors) explain the previously highlighted relationship between loan and portfolio debt borrowings. Instead, in the case of AEs corporates, the previously found pre-crisis complementarity that switched to substitution after the crisis between loans and debt borrowing seems to be driven by both the common global factors and subfactors of debt as well as the residual components of debt borrowing (see column (2) of Table 8). As in Table 2, no statistically significant relationships seem to be present in the case of inflows to AE banks. 
Table 8. Loans Inflows by Borrower Type, Common Dynamics, Advanced Economies

\begin{tabular}{|c|c|c|c|c|c|c|}
\hline Variables & $\begin{array}{c}\text { (1) } \\
\text { Loans, } \\
\text { Corporates }\end{array}$ & $\begin{array}{c}\text { (2) } \\
\text { Loans, } \\
\text { Corporates }\end{array}$ & $\begin{array}{c}\text { (3) } \\
\text { Loans, } \\
\text { Banks }\end{array}$ & $\begin{array}{c}\text { (4) } \\
\text { Loans, } \\
\text { Banks }\end{array}$ & $\begin{array}{c}\text { (5) } \\
\text { Loans, } \\
\text { Sovereigns }\end{array}$ & $\begin{array}{c}(6) \\
\text { Loans, } \\
\text { Sovereigns }\end{array}$ \\
\hline \multirow[t]{2}{*}{ debt_predicted } & 0.091 & 0.061 & 0.071 & 0.131 & $-0.231 * * *$ & $-0.273^{* *}$ \\
\hline & $(0.079)$ & $(0.130)$ & $(0.064)$ & $(0.107)$ & $(0.085)$ & $(0.123)$ \\
\hline \multirow[t]{2}{*}{ debt_predicted*crisis } & & -0.216 & & -0.158 & & -0.197 \\
\hline & & $(0.305)$ & & $(0.172)$ & & $(0.202)$ \\
\hline \multirow[t]{2}{*}{ debt_predicted*postcrisis } & & -0.027 & & -0.046 & & $0.449 *$ \\
\hline & & $(0.460)$ & & $(0.289)$ & & $(0.239)$ \\
\hline \multirow[t]{2}{*}{ debt_residuals } & $-0.308^{* * *}$ & 0.013 & -0.012 & -0.037 & $-0.297 * * *$ & $-0.105^{*}$ \\
\hline & $(0.104)$ & $(0.141)$ & $(0.053)$ & $(0.106)$ & $(0.038)$ & $(0.061)$ \\
\hline \multirow[t]{2}{*}{ debt_residuals*crisis } & & $-0.683 * * *$ & & 0.038 & & $-0.359 * * *$ \\
\hline & & (0.193) & & $(0.120)$ & & $(0.077)$ \\
\hline \multirow[t]{2}{*}{ debt_residuals*postcrisis } & & -0.29 & & -0.043 & & -0.025 \\
\hline & & $(0.276)$ & & $(0.164)$ & & $(0.115)$ \\
\hline \multirow[t]{2}{*}{ equity_predicted } & 0.419 & -1.057 & -0.393 & -0.207 & 14.719 & -17.72 \\
\hline & (1.570) & $(2.532)$ & $(0.804)$ & $(1.131)$ & $(58.056)$ & (87.927) \\
\hline \multirow[t]{2}{*}{ equity_predicted*crisis } & & 2.456 & & -1.773 & & -53.921 \\
\hline & & (3.793) & & $(2.543)$ & & (141.598) \\
\hline \multirow[t]{2}{*}{ equity_predicted*postcrisis } & & 1.726 & & 0.132 & & 63.505 \\
\hline & & (5.277) & & (2.179) & & $(173.302)$ \\
\hline \multirow[t]{2}{*}{ equity_residuals } & $-0.345^{* * *}$ & $-0.291 * *$ & -0.108 & -0.365 & 0.897 & -1.728 \\
\hline & $(0.092)$ & $(0.131)$ & $(0.210)$ & $(0.373)$ & $(1.112)$ & $(5.592)$ \\
\hline \multirow[t]{2}{*}{ equity_residuals*crisis } & & -0.172 & & -0.102 & & 2.542 \\
\hline & & $(0.216)$ & & $(0.735)$ & & $(5.716)$ \\
\hline \multirow[t]{2}{*}{ equity_residuals*postcrisis } & & -0.022 & & 0.426 & & 3.466 \\
\hline & & $(0.246)$ & & $(0.478)$ & & $(11.462)$ \\
\hline \multirow[t]{2}{*}{ misc_predicted } & -4.634 & -17.486 & 0.028 & 0.351 & $8.408^{* *}$ & $24.451 * * *$ \\
\hline & $(10.193)$ & $(22.528)$ & $(0.170)$ & $(0.301)$ & (3.573) & (9.097) \\
\hline \multirow[t]{2}{*}{ misc_predicted*crisis } & & 18.545 & & -0.441 & & $-24.088 * *$ \\
\hline & & $(25.515)$ & & $(0.408)$ & & $(9.940)$ \\
\hline \multirow[t]{2}{*}{ misc_predicted*postcrisis } & & 0.681 & & -0.908 & & -20.196 \\
\hline & & $(48.852)$ & & $(0.779)$ & & (17.888) \\
\hline \multirow[t]{2}{*}{ misc_residuals } & 0.035 & 0.351 & -0.014 & -0.009 & $-0.144 * * *$ & $-0.293 * * *$ \\
\hline & (0.149) & $(0.325)$ & $(0.015)$ & $(0.033)$ & $(0.022)$ & $(0.073)$ \\
\hline \multirow[t]{2}{*}{ misc_residuals*crisis } & & -0.434 & & -0.017 & & $0.267 * * *$ \\
\hline & & $(0.373)$ & & (0.039) & & $(0.080)$ \\
\hline \multirow[t]{2}{*}{ misc_residuals*postcrisis } & & -0.385 & & 0.029 & & 0.022 \\
\hline & & $(0.501)$ & & $(0.047)$ & & $(0.081)$ \\
\hline \multirow[t]{2}{*}{ GDP_growth (t-1) } & 0.060 & 0.046 & $0.107^{*}$ & $0.117^{*}$ & $-0.282 * * *$ & $-0.192 * * *$ \\
\hline & $(0.062)$ & $(0.063)$ & $(0.064)$ & $(0.065)$ & $(0.067)$ & $(0.065)$ \\
\hline Time FE & Yes & Yes & Yes & Yes & Yes & Yes \\
\hline Country FE & Yes & Yes & Yes & Yes & Yes & Yes \\
\hline Observations & 816 & 816 & 663 & 663 & 714 & 714 \\
\hline R-squared & 0.112 & 0.13 & 0.125 & 0.135 & 0.345 & 0.423 \\
\hline
\end{tabular}

Notes: This table reports the regression results for estimating equation (13) during the period 2003Q1-2016Q1 for advanced economies. "Crisis" dummy is 1 if an observation is between 2008Q1 to 2012Q4, and is 0 otherwise. "Post-Crisis" dummy (post) is 1 if an observation is from 2013Q1 to 2016Q1, and is 0 otherwise. A constant as well as time and borrower country fixed effects were included but they are not reported. Robust standard errors are in parentheses. Asterisks denote significance of coefficients, with $* * *, * *, *$ indicating significance at $1 \%, 5 \%$, and $10 \%$ level, respectively. 
Table 9. Loans Inflows by Borrower Type, Common Dynamics, Emerging Economies

\begin{tabular}{|c|c|c|c|c|c|c|}
\hline Variables & $\begin{array}{c}\text { (1) } \\
\text { Loans, } \\
\text { Corporates }\end{array}$ & $\begin{array}{c}\text { (2) } \\
\text { Loans, } \\
\text { Corporates }\end{array}$ & $\begin{array}{c}\text { (3) } \\
\text { Loans, } \\
\text { Banks }\end{array}$ & $\begin{array}{c}\text { (4) } \\
\text { Loans, } \\
\text { Banks }\end{array}$ & $\begin{array}{c}\text { (5) } \\
\text { Loans, } \\
\text { Sovereigns } \\
\end{array}$ & $\begin{array}{c}(6) \\
\text { Loans, } \\
\text { Sovereigns } \\
\end{array}$ \\
\hline \multirow[t]{2}{*}{ debt_predicted } & -0.374 & -0.272 & 0.177 & $0.814 * *$ & 0.005 & -0.060 \\
\hline & $(0.516)$ & $(0.932)$ & $(0.210)$ & $(0.347)$ & (0.110) & $(0.205)$ \\
\hline \multirow[t]{2}{*}{ debt_predicted*crisis } & & -0.154 & & $-1.011^{* *}$ & & 0.158 \\
\hline & & (1.273) & & $(0.492)$ & & $(0.253)$ \\
\hline \multirow[t]{2}{*}{ debt_predicted*postcrisis } & & $0.377^{* *}$ & & $0.185^{*}$ & & 0.02 \\
\hline & & $(0.178)$ & & (0.099) & & $(0.080)$ \\
\hline \multirow[t]{2}{*}{ debt_residuals } & 0.07 & -0.188 & -0.035 & -0.078 & $-0.126 * * *$ & $-0.140 * *$ \\
\hline & $(0.072)$ & $(0.128)$ & $(0.045)$ & $(0.060)$ & $(0.030)$ & $(0.065)$ \\
\hline \multirow[t]{2}{*}{ debt_residuals*crisis } & & $0.377^{* *}$ & & $0.185^{*}$ & & 0.02 \\
\hline & & $(0.178)$ & & (0.099) & & $(0.080)$ \\
\hline \multirow[t]{2}{*}{ debt_residuals*postcrisis } & & $0.398 * *$ & & 0.181 & & 0.001 \\
\hline & & $(0.168)$ & & $(0.208)$ & & (0.084) \\
\hline \multirow[t]{2}{*}{ equity_predicted } & $-0.244^{*}$ & $-0.466 * *$ & $-2.244 * * *$ & $-3.370 * * *$ & 2.45 & -0.374 \\
\hline & $(0.139)$ & $(0.194)$ & $(0.542)$ & $(0.786)$ & (4.461) & (6.167) \\
\hline \multirow[t]{2}{*}{ equity_predicted*crisis } & & $0.588^{*}$ & & $1.990^{*}$ & & -91.176 \\
\hline & & $(0.311)$ & & (1.208) & & (90.795) \\
\hline \multirow[t]{2}{*}{ equity_predicted*postcrisis } & & 0.595 & & 2.297 & & -33.594 \\
\hline & & $(0.586)$ & & $(2.141)$ & & (132.859) \\
\hline \multirow[t]{2}{*}{ equity_residuals } & 0.083 & -0.109 & 0.038 & 0.032 & -1.341 & 0.283 \\
\hline & (0.079) & (0.101) & $(0.068)$ & (0.069) & (3.428) & (4.313) \\
\hline \multirow[t]{2}{*}{ equity_residuals*crisis } & & $0.504 * * *$ & & 0.27 & & -84.582 \\
\hline & & $(0.171)$ & & $(0.391)$ & & (88.647) \\
\hline \multirow[t]{2}{*}{ equity_residuals*postcrisis } & & 0.34 & & -0.754 & & -61.153 \\
\hline & & $(0.230)$ & & $(0.643)$ & & (130.807) \\
\hline \multirow[t]{2}{*}{ misc_predicted } & 0.148 & -0.053 & $-0.147^{*}$ & $-0.402 * *$ & $-1.332 * * *$ & -0.634 \\
\hline & $(0.227)$ & $(0.431)$ & $(0.077)$ & $(0.161)$ & $(0.305)$ & (1.239) \\
\hline \multirow[t]{2}{*}{ misc_predicted*crisis } & & 0.065 & & $0.423^{* *}$ & & -0.848 \\
\hline & & $(0.566)$ & & $(0.202)$ & & (1.285) \\
\hline \multirow[t]{2}{*}{ misc_predicted*postcrisis } & & 0.764 & & 0.286 & & 0.983 \\
\hline & & $(0.667)$ & & $(0.223)$ & & $(1.770)$ \\
\hline \multirow[t]{2}{*}{ misc_residuals } & -0.024 & 0.043 & 0.001 & $-0.049 *$ & $-0.132 * * *$ & -0.014 \\
\hline & $(0.040)$ & $(0.078)$ & $(0.016)$ & $(0.026)$ & $(0.030)$ & $(0.057)$ \\
\hline \multirow[t]{2}{*}{ misc_residuals*crisis } & & -0.046 & & $0.086^{* *}$ & & -0.009 \\
\hline & & (0.106) & & $(0.037)$ & & $(0.089)$ \\
\hline \multirow[t]{2}{*}{ misc_residuals*postcrisis } & & -0.128 & & 0.078 & & $-0.233 * * *$ \\
\hline & & $(0.101)$ & & $(0.056)$ & & $(0.072)$ \\
\hline \multirow[t]{2}{*}{ GDP_growth (t-1) } & $0.037 * * *$ & $0.033 * * *$ & 0.008 & 0.008 & $-0.045^{* *}$ & $-0.042 * *$ \\
\hline & $(0.012)$ & $(0.012)$ & $(0.016)$ & $(0.016)$ & $(0.019)$ & (0.019) \\
\hline Time FE & Yes & Yes & Yes & Yes & Yes & Yes \\
\hline Country FE & Yes & Yes & Yes & Yes & Yes & Yes \\
\hline Observations & 1,020 & 1,020 & 918 & 918 & 561 & 561 \\
\hline R-squared & 0.297 & 0.316 & 0.19 & 0.217 & 0.204 & 0.241 \\
\hline
\end{tabular}

Notes: This table reports the regression results for estimating equation (13) during the period 2003Q1-2016Q1 for advanced economies. "Crisis" dummy is 1 if an observation is between 2008Q1 to 2012Q4, and is 0 otherwise. "Post-Crisis" dummy (post) is 1 if an observation is from 2013Q1 to 2016Q1, and is 0 otherwise. A constant as well as time and borrower country fixed effects were included but they are not reported. Robust standard errors are in parentheses. Asterisks denote significance of coefficients, with $* * *, * *, *$ indicating significance at $1 \%, 5 \%$, and $10 \%$ level, respectively 
Columns (2), (4) and (6) of Table 9 report the results of emerging economies including the crisis and post-crisis dummy. While difficult to find specific patterns, common movements by instrument type (as predicted by factors) result in more statistically significant coefficients than those in advanced economies. This is probably capturing the fact that inflows to EM are more susceptible to the global financial cycle, including in the case of inflows to EM banks. However, at the same time, idiosyncratic components (residuals) also exhibit significant relationships with loans borrowing. This is especially the source of variations that seems to explain the previously-found complementarity between loans and debt inflows to EM corporates after the crisis (see column (2) of Table 9).

\section{Conclusions}

Our analysis of the evolution of disaggregate gross capital inflows during the period 2003-16, taking both types of instrument and borrower heterogeneity into account, shows there has been substitution between loan and portfolio debt inflows to AE corporates and AE sovereigns. This contradicts the aggregate capital inflow movements highlighted by part of the literature (see Bussière et al 2016), but is in line with firm-level data analysis (e.g., the one performed by Becker and Ivashina 2014 on US companies). However, inflows to EM corporate seem to be more of the complementarity nature. This is most likely capturing the effect of the global financial cycle on the inflows to EM, a phenomenon widely studied in the literature using aggregated data. The private sector in most EMs cannot probably systematically perform debt optimization operations (e.g., evaluating recursively debt versus loans borrowing tradeoffs) since it is likely constrained on how much it can borrow. This would explain why the two main types of gross capital inflows (loans and debt) are positively correlated for EM private borrowers. When conditions are favorable (e.g., low interest rates in US and/or other global financial centers), the private sector in EMs, at the aggregate level, would take advantage and increase its external borrowing. These borrowing constraints seem not to be as important in the case of EM sovereigns. Like AE corporates (since the crisis) and AE sovereigns, EM sovereigns seem to be able to substitute borrowing through loans and debt securities.

Through the analysis of the evolution of the common factors (global and sub-factors) as well as the regressions with predicted and residual decompositions, it seems clear that the global financial cycle alone is not driving the complementarity/substitution patterns. Our results indicate that, even in the case of capital inflows to EMs, a large part of the complementarity/substitution patterns are not driven by a common phenomenon linked to the global financial cycle, but rather by country-specific factors. This is consistent with Cerutti, Claessens, and Rose (2017), which finds little systematic evidence that the global financial cycle explains a large fraction of the variation in capital flows to emerging markets and peripheral advanced countries.

Finally, we confirm the presence of substantial heterogeneity across borrowing sectors in both AEs and EMs, especially between public and private sectors. In this context, we would 
certainly recommend to exclude inflows to the public sector as much as possible when analyzing the pattern of gross inflows along the global financial cycle. 


\section{References}

Advjiev, S. B. Hardy, S. Kalemli-Özcan, L. Servén, 2017. "Gross Capital Flows into Banks, Corporates and Sovereigns," NBER Working Paper Series. 23116.

Barrot, Luis-Diego,and Luis Servén, 2017. "Gross Capital Flows, Common Factors, and the Global Financial Cycle" mimeo, World Bank.

Becker, Bo and Victoria Ivashina, 2014. "Cyclicality of Credit Supply: Firm Level Evidence," Journal of Monetary Economics, vol. 62, pp. 76-93.

Blanchard, O. and J. Acalin, (2016), "What does Measured FDI Actually Measure?" Peterson Institute Policy Brief no. PB16-17.

Bluedorn, J., Duttagupta, R., Guajardo, J. and P. Topolova (2013), “Capital Flows are Fickle: Anytime, Anywhere," IMF Working Paper no.13/183.

Broner, F., T. Didier, A. Erce, and S. Schmukler, 2013, "Gross Capital Flows: Dynamics and Crises," Journal of Monetary Economics Vol. 60, No. 1, pp. 113-33.

Bruno, V., and H. S. Shin, 2015a. "Cross-border banking and global liquidity," Review of Economic Studies Vol. 82, pp. 535-564.

Bruno, V., and H. S. Shin, 2015b. "Capital flows and the risk-taking channel of monetary policy." Journal of Monetary Economics, Vol. 71, pp. 119-132.

Bussière, M. J. Schmidt and N. Valla, 2016. "International Financial Flows in the New Normal: Key Patterns (and Why We Should Care)", CEPII Policy Brief, March.

Cerutti, E., and S. Claessens, 2017, "The Great Cross-Border Bank Deleveraging: Supply Side Characteristics and Intra-Group Frictions," Review of Finance, vol. 21 (1), pp. 201236.

Cerutti, E., S. Claessens, and D. Puy, 2015, "Push Factors and Capital Flows to Emerging Markets: Why Knowing Your Lender Matters More Than Fundamentals, IMF Working Paper 15/267.

Cerutti, E., S. Claessens, and L. Ratnovski, 2017, "Global Liquidity and Cross-Border Bank Flows," Economic Policy, vol.32 (89), pp. 81-125.

Cerutti, E., S. Claessens, and A. Rose, 2017, "How Important is the Global Financial Cycle? Evidence from Capital Flows," NBER Working Paper No 23699.

Cerutti, E., and C. Osorio-Buitron, 2017, "US vs. Euro Area: Who drives cross-border bank lending to EMs?" mimeo.

Cerutti, E., and H. Zhou, 2017, "The Global Banking Network in the Aftermath of the Crisis: Is There Evidence of De-globalization?” IMF Working Paper 17/232.

Claessens, S., M. Dooley, and A. Warner, 1995, “Portfolio Capital Flows: Hot or Cold?” The World Bank Economic Review, vol 9(1), pp. 153-174.

Eichengreen, B., Gupta, P., and O. Masetti, 2017. "Are Capital Flows Fickle? Increasingly? And Does the Answer Still Depend on Type?" World Bank Policy Research Working Paper No 7972.

Fernandez, C., E. Ley, and M. Steel, 2001, "Benchmark Priors for Bayesian Model 
Averaging," Journal of Econometrics, Vol. 100, No. 2, pp. 381-427.

Forbes, K, D Reinhardt and T Wieladek (2017), "The Spillovers, Interactions, and (Un)Intended Consequences of Monetary and Regulatory Policies" Journal of Monetary Economics, 85, pp. 1-22.

Forbes, Kristin J., and Francis E. Warnock, 2012, "Capital flow waves: Surges, stops, flight, and retrenchment” Journal of International Economics, Vol. 88, N0. 2, pp. 235-251.

Galstyan, V., P. Lane, C. Mehigan, and R. Mercado, 2016. "The Holders and Issuers of International Portfolio Securities.” NBER Working Paper No. 22466.

Hoggarth, G., C.Jung and D. Reinhardt, 2016. "Capital Inflows- the Good, the Bad and the Bubbly," Financial Stability Paper 40, October, Bank of England.

Jensen, M., and W. Meckling, 1976. "Theory of the firm: managerial behavior, agency costs, and ownership structure." Journal of Financial Economics, 3 , pp. 305-360

Koepke, R., 2015, "What Drives Capital Flows to Emerging Markets: A Survey of the Empirical Literature," IIF Working Paper, April, Washington D.C.

Kose, A., C. Otrok and C. Whiteman, 2003. "International Business Cycles: World, Region, and Country-Specific Factors," American Economic Review, 93 (4), 1216-239.

Lane. P., and G. M. Milesi-Ferretti (2016), "International Financial Integration in the Aftermath of the Global Financial Crisis", presentation, IMF Annual Research Conference.

Lo Duca, M. G. Nicoletti and A. Martinez, 2014. "Global Corporate Bond Issuances. What Role for US quantitative Easing?” ECB Working Paper No. 1649.

Milesi-Ferretti, G. M., and Cédric Tille, 2011, “The Great Retrenchment: International Capital Flows during the GFC," Economic Policy, Vol. 26. No. 66, pp. 285-342.

Modigliani, F., and M. Miller, 1963. "Corporate income taxes and the cost of capital: a correction." American Economic Review, 53, pp. 433-443

Neely, C.J. and Rapach, D.E, 2011. "International Comovements in Inflation Rates and Country Characteristics," Journal of International Money and Finance, 30, 1471-1490.

Obstfeld, M., 2012. "Does the Current Account Still Matter?” NBER Working Paper No. 17877.

Passari, E. and H. Rey, 2015. "Financial Flows and the International Monetary System" Economic Journal 125, 675-698

Reinhart, C., and K.S. Rogoff, 2009. "This Time is Different: Eight Centuries of Financial Folly." Princeton University Press, Princeton, New Jersey.

Shin, H.S., 2012 "Global Banking Glut and Loan Risk Premium” Mundell-Fleming Lecture, IMF Economic Review 60 (2), 155-192

Shin, H.S., 2013. Second phase of global liquidity and its impact on emerging economies. In: Proceedings of the Keynote Address at the Federal Reserve Bank of San Francisco Asia Economic Policy Conference, November 3-5, 2013. 